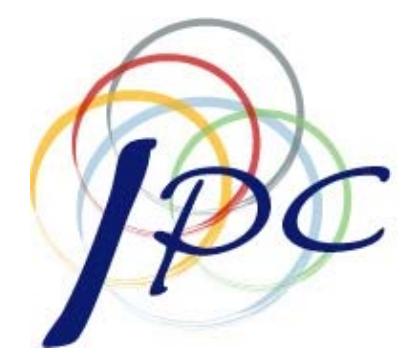

International Policy Center

Gerald R. Ford School of Public Policy University of Michigan

IPC Working Paper Series Number 79

Storm in a spaghetti Bowl: FTAs and the BRIICS

\author{
Kozo Kiyota \\ Margit Molnar \\ Robert M. Stern
}

December 9, 2008 


\title{
Storm in a Spaghetti Bowl: FTA's and the BRIICS
}

\author{
by
}

Kozo Kiyota, Margit Molnar and Robert M. Stern

\section{Introduction}

The six BRIICS countries (Brazil, Russia, India, Indonesia, China and South Africa) are strongly integrated in global trade as well as having generally dynamic economic performance. This integration has partly been driven by their proliferating FTAs with their major trade partners and with countries in their regions.

In this study we analyse the welfare and sectoral effects of a variety of options for the formation of free trade agreements by the BRIICS economies. These options include FTAs involving OECD countries in the region of the respective BRIICS country as a base scenario, then adding to the list of FTA partners other feasible OECD countries, China, ASEAN and India. There are altogether, five computational scenarios.

The analysis here is carried out using the Michigan Model of World Production and Trade, which is a multi-country, multi-sectoral computational general equilibrium (CGE) model of the global trading system. The version of the model that we use includes 31 countries/regions plus the rest-of-world and 27 sectors in each country/region. The main data source used in the model is "The GTAP-6.0 Database" of the Purdue University Center for Global Trade Analysis Project (Dimaranan and McDougall, 2005). A detailed description of the Michigan model of World Production and Trade is included in the Annex.

In Section II we present the computational results for the BRIICS bilateral FTAs, focusing on the effects on economic welfare and the sectoral effects on output, exports, imports, employment. To provide some perspective on the FTA results, we present in Section III welfare comparisons of the BRIICS FTAs with the effects of unilateral free trade and global free trade. Conclusions and implications for further research are presented in Section IV.

\section{How Large an Impact May BRIICS FTAs Bring About?}

An important measure to evaluate FTAs is their impact on global welfare and on output, trade and employment in participating countries. We ran five FTA scenarios for the BRIICS countries to evaluate these impacts. Each FTA scenario differs somewhat depending on the country pairs included (for the detailed pairs, see Annex Table 5A.1). In the first scenario, it is assumed that each of the BRIICS countries signs an FTA with the major OECD trade partner in its respective region. Then, in the second scenario, FTAs between BRIICS and other OECD countries are assumed to be formed. In the third scenario the BRIICS are assumed to enter into an FTA with China, in addition to likely OECD-BRIICS bilateral agreements. In Scenario 4, FTAs are assumed to be formed involving ASEAN, and, in Scenario 5, with India. The AFTA (Asian Free Trade Area) is assumed to be an FTA in all scenarios.

The unique feature in modelling the individual scenarios is that we assume in each case that the country-pair FTAs are carried out simultaneously. That is, the effects on individual BRIICS countries take into account both the direct effects of each BRIICS FTA on the individual country/region noted as well as the cross effects of all other FTAs included in the scenario.

It is not surprising that FTAs bring about specialisation in all participating countries according to their comparative advantage. Moreover, this specialisation is stronger the more FTAs in which countries 
are involved. For smaller countries, this specialisation may reshape the sectoral landscapes. That is, a large shift of labour is observed in countries with a comparative advantage in labour-intensive manufacturing (sometimes also in some agriculture and services sectors), which, due to the full employment assumption, implies shifts of labour out of other sectors and reduced output in these sectors. Nevertheless, the net output and welfare effects remain positive. Let us then consider the various modelling results.

\section{Global Welfare Effects}

A primary interest in this chapter is to determine the effects of the different BRIICS countries FTAs in terms of global welfare. The welfare impacts to be noted are expressed in millions of US dollars (USD) and as a percentage of GDP for the 31 countries/regions covered in the model. As will be noted, the global welfare effects are comparatively small.

In Scenario 1, the greatest absolute increases in welfare occur for the major industrialised countries, that is, Japan, United States, and the EU/EFTA, for which bilateral FTAs are assumed to be carried out (see Annex Table 5A.2). It is interesting to note that the increase in terms of absolute values is the greatest for Japan, which takes part in three FTAs in this scenario. Japan is followed by the EU (which is assumed to take part in two FTAs). The welfare increase for the United States (assumed to have only one FTA) is less than half of that for Japan and the EU. However, these welfare increases are all relatively small as a percentage of GDP, noticeably less than $1 \%$.

All the BRIICS except China (which records a small decrease) experience fairly small absolute and percentage increases in welfare. In this scenario, Russia's gains are the largest among the BRIICS countries at $2.1 \%$ of GDP. This reflects the importance of the EU market for Russia.

In Scenarios 2-5 the global and country/region welfare effects can be seen to increase somewhat when particular FTAs are expanded to include more bilateral partners, Annex tables 5A.3-5A.6. The welfare effect for China becomes positive in Scenarios 3-5 with the addition of more FTA partners. It is further noteworthy that most of the bilateral FTAs have positive effects on non-participating countries/regions. Thus, in general, there is not much evidence of trade diversion. The only exceptions are for China's FTAs that show small negative welfare impacts in some cases on a number of developing countries in Asia and Latin America.

In comparing the scenarios, it is clear that the involvement of more OECD countries in FTAs results in larger global welfare increases, while the increase of global welfare from more FTAs among BRIICS themselves is relatively small. In particular, China's FTAs with other BRIICS only bring about a very marginal global welfare increases. These findings may be related to the similarities in comparative advantages among BRIICS and also to the greater importance of trade barriers between OECD and BRIICS countries than between BRIICS.

\section{Sectoral Effects}

While the global effects of FTAs involving the BRIICS countries may not be very large, there may be significant sectoral shifts within countries. That is, as a result of the assumed formation of additional FTAs, BRIICS countries become increasingly specialised in sectors in which they have comparative advantage. This may draw away resources from other sectors owing to the assumption of full employment and thus result in declining output in those sectors. Nevertheless, the net impact remains positive in most cases. The results of changes in exports, imports, output, and employment by sector for the individual 
BRIICS countries, Japan, EU/EFTA, and the United States for each scenario can be found in Kiyota, Molnar, and Stern (KMS) (2008). ${ }^{1}$

\section{Brazil}

It is assumed that Brazil signs an FTA with the United States only in the first scenario and also with the EU/EFTA in the other scenarios. The sectoral results for a Brazil-US FTA show that Brazil's exports increase across all of its sectors. These results for Brazil reflect the effects both of the Brazil-U.S. FTA together with the other FTAs included in Scenario 1 (Annex Table 5A.7). The most remarkable increase is seen in the exports of leather products and footwear, in which Brazil has strong comparative advantage. The increase in exports in absolute terms is also large in transportation equipment, food and beverages and chemicals (though not in percentage terms). The sectoral effects on Brazil's imports, output, and employment are given in KMS (2008) and are available on request. Brazil's imports of agricultural and mineral products decline while imports of capital-intensive manufactures services expand noticeably. Outputs rise moderately in all sectors except in chemicals, machinery \& equipment, and services. There are employment increases in Brazil's agricultural and mineral sectors, textiles, leather products \& footwear, wood \& wood products and transportation equipment, and employment declines in wearing apparel, chemicals, non-metallic and metal products, machinery \& equipment and services. The percentage changes in employment are comparatively small, except for the $10.3 \%$ employment increase in leather \& leather products.

In Scenario 2, where Brazil signs an FTA with the US and the EU, the sectoral impacts are considerably greater than in Scenario 1 (Brazil-US FTA). The detailed results are reported in KMS (2008) and are available on request. Exports and imports increase in almost all sectors. The expansion and contraction of outputs are considerably greater across Brazil's sectors. The employment increases and declines are also much larger in absolute and percentage terms with the expanded FTA, and these changes suggest that some measures of adjustment assistance might be warranted to moderate the employment reallocation involved. As reported in KMS (2008), the results in Scenarios 3-5 - where Brazil maintains its FTA assumptions with the US and the EU but there are additional FTAs between other BRIICS and OECD countries - differ slightly from those in Scenario 2, reflecting the variations in the other BRIICS FTAs that are being taken into account.

\section{Russia}

All five scenarios include a Russia-EU FTA as it is assumed unlikely for Russia to sign an FTA with other BRIICS or other major OECD countries. Notwithstanding Russia's assumed limited participation in FTAs, its gains are large and relatively constant across all scenarios. Only China registers larger gains in terms of exports in any scenario and no country in terms of output. Large gains from an FTA with a single economic area reflect the large potential of that market for Russia and the presence of substantial existing trade barriers. The finding that gains are constant across scenarios suggests that Russia is not affected much by trade diversion related to other countries' FTAs. This is not so surprising given the relative uniqueness of Russia's comparative advantages in mining and other products.

In Scenario 1 there are small changes in Russia's exports and imports of agricultural products, significant increases in other exports, a small decline in imports of mineral products and an expansion of exports and imports of manufactures and services, Annex Table 5A.7 and KMS (2008). The large overall

1 The computational results presented reflect both the direct effects of the bilateral FTAs and the effects of the other FTAs assumed to be undertaken. In other words, the results reflect the direct effects of the bilateral FTAs as well as trade creation and trade version effects from other FTAs. 
output gain stems mainly from gains in the mining, metal products and chemicals sectors - over 100000 jobs are created in the metal products sector. Outputs fall to some extent in the agricultural sectors and leather \& leather products and increase in other sectors. Employment declines broadly across most of the agricultural sectors and to some extent in manufactures and services. Employment increases noticeably in natural resources, mineral products, wearing apparel, chemicals and metal products. The sectoral results in the other scenarios remain unchanged: Russia remains the biggest gainer among the BRIICS in terms of output. The large output gains may be related to the increase in exports and the shift of employment to sectors where the per employee output is large such as in metal products, mining, and chemicals. Employment is reduced in sectors where the value of output per employee is small such as in food and beverages and leather products.

\section{India}

India is assumed to participate in FTAs with Japan only in Scenario 1, with Japan and the United States in Scenarios 2-3, with Japan, United States and ASEAN in Scenario 4 and with Japan, United States, ASEAN and China in Scenario 5. The output gains related to the FTAs are much smaller for India than for China or Russia and most of the time even for Indonesia. In terms of exports, an FTA with the ASEAN in addition to the FTAs with Japan and the United States brings about substantial gains.

The results of Scenario 1, where India signs an FTA with Japan only, indicate small increases in exports (Annex Table 5A.7). As reported in KMS (2008), there are declines in imports of agricultural and mineral products, wearing apparel and leather \& leather products, and sizable increases in imports of capital-intensive manufactures. There are increases in output in some agricultural sectors, mineral products, textiles and wearing apparel, other manufactures, and some services sectors. There are employment increases especially in mineral products, food, beverages \& tobacco, labour-intensive manufactures, trade \& transport, and other private services. The employment changes are relatively small in percentage terms. The limited export gains from an FTA with Japan may be related to trade diversion by China and Indonesia that also are assumed to have an FTA with Japan in this scenario.

Scenario 2 involves an FTA between India-Japan and India-United States. As noted in KMS (2008), the most notable output changes are a sizable increase in output and employment in plant-based fibres and declines in all other agricultural and food sectors. The output and employment increases are concentrated in labour-intensive manufactures and other private services. There are employment declines in capital-intensive manufactures and most services. The sectoral results in Scenario 3 are more or less comparable since Scenario 3 refers to the same India FTA as Scenario 2.

Scenario 4 adds ASEAN to India's FTA with Japan and the United States. The patterns of the changes parallel those in Scenario 3, but the positive and negative effects are now much larger. Scenario S5 adds China to India's FTA with Japan, the United States, and ASEAN. The patterns of change in Scenario 5 are similar to those in Scenario 4, but the negative and positive effects now are significantly larger with the addition of China.

\section{Indonesia}

Indonesia, as a member of ASEAN, is assumed to trade freely with all other AFTA members in all scenarios. In addition, in Scenario 1, it participates in an FTA with Japan and in Scenario 2 also with the United States. In Scenario 3, China is added as an FTA partner and in Scenario 4, in addition to the partners in Scenario 3, India has an FTA with the ASEAN. The FTA partners for Indonesia do not change in Scenario 5. 
Scenario 1 refers to an FTA involving Indonesia together with the other ASEAN members and Japan. With the recent establishment of an EPA (Economic Partnership Agreement) between Japan and Indonesia, this part of Scenario 1 has now become reality. Indonesia's export increases are concentrated in food, beverages \& tobacco, textiles and wearing apparel, wood \& wood products, and transportation machinery (Annex Table 5A.7). As reported in KMS (2008), import increases are substantial in food, beverages \& tobacco, chemicals, capital-intensive manufactures, trade \& transport, and other private services. Substantial increases in both exports and imports in the food and beverages and transport equipment sectors may be related to product variety. There are sizable increases in sectoral output in natural resource products, food, beverages \& tobacco, textiles \& wearing apparel, wood \& wood products, and machinery \& equipment. Employment increases in several agricultural sectors, natural resources, textiles and wearing apparel, wood \& wood products and machinery \& equipment. There are employment declines in oil seeds and sugar, chemicals, transportation equipment and services.

Scenario 2 takes into account an enlargement of the Indonesian FTA to include the United States. There are now more negative output and employment impacts across the Indonesian agricultural, natural resource and mineral sectors, manufactures, and services, KMS (2008). Output and employment increases are significant in labour-intensive manufactures such as wearing apparel. ${ }^{2}$ Scenario 3 reflects an enlargement of the Indonesian FTA to include China. In this scenario, Indonesia's rice and natural resource sectors expand, as do the labour-intensive manufactures. There are declines across the other agricultural sectors, minerals, capital-intensive manufactures and services. The results of this scenario show that China's effect on Indonesia is far from being as negative as feared by many. That is, Indonesia is not turning into a natural resource-supplier. On the contrary, even in a setting of free trade with China, Indonesia is able to expand its wearing apparel, textiles and leather exports significantly. This reflects Indonesia's strong comparative advantages and market positions in these sectors.

Scenario 4 considers a further enlargement of an Indonesian FTA to include India. Indonesia's rice sector further expands together with sugar, plant-based fibres, and livestock. The output and employment increases for labour-intensive manufactures and decreases across the remaining manufactures sectors and services are comparable to Scenario 3. The results for Scenario 5 are broadly similar to those in Scenario 4, with the differences reflecting the other BRIICS FTAs included in Scenario 5.

\section{China}

China is assumed to participate in an FTA with Japan in all scenarios. In addition, in Scenario 3, it is assumed to have an FTA with Indonesia, in Scenario 4 with the ASEAN, and in Scenario 5 with India. Among all BRIICS countries, China registers by far the largest export gains in all scenarios, reflecting its comparative advantage in a wide range of product categories - in particular in labour-intensive manufacturing industries. Its output declines though in the first two scenarios and increases only slightly in the third. FTAs with ASEAN and India, however, also bring about substantial output increases.

Scenario 1 refers to an FTA between China and Japan. As noted in Table A5.7, China's exports of agricultural products, food, beverages \& tobacco, labour-intensive manufactures, and services increase. According to KMS (2008), its imports are concentrated in textiles and capital-intensive manufactures. There are sizable increases in output and employment across the agricultural and labour-intensive manufacturing sectors and declines in the capital-intensive and services sectors. The sectoral results in Scenario 2 are broadly similar, reflecting the variations in FTAs in Scenario 2.

2 It should be noted that as the year 2001 is chosen for benchmark, the gains related to the phase out of quotas under the MFA in 2005 have not been taken into account. Therefore, the actual gains in the textiles and clothing sectors related to the FTAs may be somewhat smaller. 
While Scenario 3 adds Indonesia to a China-Japan FTA, the sectoral results are broadly similar to those for Scenario 2. The same is true for Scenario 4 in which ASEAN replaces Indonesia in a China-Japan FTA. Scenario 5 involves an FTA for China together with Japan, ASEAN, and India. Here also the sectoral results are broadly parallel to those in the preceding discussion.

\section{South Africa}

Scenarios 1-5 all involve an FTA between South Africa and the EU. The sectoral results are thus broadly similar, reflecting the variations in the FTAs for the other BRIICS countries that are taken into account. The major positive sectoral changes that occur for South Africa are concentrated in its agricultural and mineral sectors and in metal products. There are negative employment effects across the remainder of manufactures and all of the services sectors. The magnitude of gains both in terms of exports or output remains limited for South Africa, Annex Tables 5A.7 and 5A.8. This contrasts with the results for Russia, which registers sizable gains both in terms of exports and output. To a limited extent this difference may be related to trade diversion by other FTAs, but overall it reflects the fact that South Africa's comparative advantages are in a more limited product range.

\section{Japan}

The sectoral effects for Japan reflect both the effects of the various FTAs for which Japan is a partner as well as the effects of all other FTAs on Japan in the individual Scenarios 1-5. It can be seen that Japan's manufactures expand considerably (Annex Table 5A.7). Japan's imports of agricultural, natural resource, and mineral products increase somewhat, and there are significant increases in imports of all manufactures, especially food, beverages \& tobacco and labour-intensive products and services, KMS (2008). The changes in output and employment reflect the changes in trade, with declines in agricultural, natural resource and mineral products and labour-intensive manufactures. There are significant increases in output and employment in textiles, capital-intensive manufactures and services. The foregoing changes are broadly reflected in Scenarios 2-5 that cover somewhat different FTA arrangements.

\section{EU/EFTA}

The EU/EFTA is assumed to participate in FTAs with Russia and South Africa in all scenarios and in addition with Brazil in Scenarios 2-5. In Scenario 1, as reported in Table A5.7, EU/EFTA exports of vegetables and fruits and other crops increase somewhat, and exports increase for most of the manufactures and services sectors. EU/EFTA imports increase to some extent across most of the agricultural, natural resource and mineral, manufactures and services sectors, KMS (2008). Output and employment rise somewhat in most agricultural sectors, food, beverages \& tobacco, chemicals, non-metallic mineral products, transportation equipment and services. There are declines in output and employment in mineral products and labour-intensive manufactures. Employment also declines in metal products and machinery \& equipment.

The sectoral pattern and magnitudes of change are somewhat different in Scenarios 2, reflecting the inclusion of an FTA involving Brazil together with the United States and EU/EFTA. The main differences are increased negative impacts on the EU/EFTA agricultural and food, beverages \& tobacco sectors and labour-intensive manufactures. The pattern and magnitudes of changes noted are broadly similar to those in Scenario 2, reflecting the various FTAs that are being covered.

\section{United States}

In Scenario 1, with a Brazil-U.S. FTA, U.S. exports of agricultural products and labour-intensive manufactures decline while exports of capital-intensive manufactures and services increase, 
Annex Table 5A.7. U.S. imports increase to some extent in virtually all of the sectors shown, KMS (2008). There are declines in output and employment in most US agricultural sectors, labour-intensive manufactures, metal products, and other products. The main increases in output and employment are in the U.S. capital-intensive sectors and services: although they are fairly small in percentage terms.

When the United States expands its FTAs to include India and Indonesia (in addition to Brazil) the pattern and magnitudes of the sectoral effects change somewhat in the agricultural sectors. Output becomes more negative in labour-intensive manufactures and more positive in the capital-intensive sectors and in services. The sectoral results in Scenarios 3-5 appear broadly similar to those in Scenario 2.

\section{Computational Results for Unilateral Free Trade and Global Free Trade}

Having analysed the economic effects of a variety of BRIICS FTAs in our different scenarios, it is of interest to compare the FTA results with the assumed adoption of unilateral free trade by the individual BRIICS nations and global (multilateral) free trade by all of the countries/regions covered in the Michigan Model. The top part of Annex Table 5A.9 summarises the welfare effects on each of the six BRIICS nations of the FTAs included in Scenarios 1-5. These effects and the global totals take into account the simultaneous implementation of all of the FTAs covered in each scenario. The bottom left part of the table contains the welfare effects for the BRIICS nations that would result from unilateral trade liberalisation, both in terms of the impacts on the individual countries and the associated global effects. The bottom right part of the table indicates the changes in welfare for the BRIICS nations that would result from all 31 countries/regions eliminating all of their trade barriers multilaterally.

Brazil's economic welfare is projected to increase from USD 2.4 to USD 6.4 billion $(0.27-0.71 \%$ of GDP) based on the five FTA options in Scenarios 1-5. This compares with welfare improvements of USD 26.0 billion (2.91\% of GDP) from unilateral liberalisation and USD 26.4 billion (2.94\% of GDP) from global free trade. Russia gains between USD 11.5 and USD 11.8 billion from its FTA options compared to USD 24.9 billion (4.53\% of GDP) from unilateral liberalisation and USD 41.0 billion (7.48\% of GDP) from global free trade. India gains from USD 2.1 to USD 18.0 billion $(0.24-2.12 \%$ of GDP) with FTAs compared to USD 28.8 billion (3.40\% of GDP) from unilateral liberalisation and USD 50.0 billion (5.89\% of GDP) from global free trade. Indonesia gains between USD 4.4 and USD 13.3 billion (1.70-5.16\% of GDP) from FTAs compared to USD 12.1 billion (4.70\% of GDP) from unilateral liberalisation and USD 26.6 billion (10.30\% of GDP) from global free trade. China gains from minus USD 0.07 and USD 18.8 billion (-0.03-0.91\% of GDP) from FTAs compared to USD 107.1 billion (5.19\% of GDP) from unilateral liberalisation and USD 131.4 billion (6.37\% of GDP) from global free trade. South Africa gains around USD 2.6 billion (1.28-1.35\% of GDP) from its FTA's compared to USD 12.0 billion (5.94\% of GDP) from unilateral liberalisation and USD 16.2 billion (8.05\% of GDP) from global free trade.

These results add evidence to the contention that the welfare benefits to the BRIICS economies from unilateral or global (multilateral) free trade are much greater than the benefits to be derived from FTAs. Furthermore, this would be the case even if there would be less than complete free trade globally. That is, if existing trade barriers were to be reduced multilaterally by one-third or one-half, for example, the resulting global and national gains would be proportionally lower. However, the global free trade gains are generally so much larger than they are for FTAs that global freer trade can be considered superior to FTAs. Furthermore, there are a range of other negative features to FTA's including complex sets of rules of origin. Accordingly, even if there were be positive non-trade and dynamic benefits from foreign direct investment and increased capital formation stemming from the FTAs that are not accounted for here, FTAs are unlikely to be superior to multilateral freer trade. 


\section{Conclusions and Implications for Further Research and Policy}

The computational analysis that we have presented has been based on the Michigan Model of World Production and Trade, which is a multi-country/multi-sector computable general equilibrium (CGE) model that has been used for over three decades to provide estimates of the economic effects of multilateral, regional, and bilateral trade negotiations and other aspects of changes in trade policies of the world's major trading countries/regions. The version of the model used covers 27 economic sectors, including agriculture, manufactures, and services, in each of 31 countries/regions. The distinguishing feature of the Michigan Model is that it incorporates elements of imperfect competition, including increasing returns to scale, monopolistic competition, and product variety. The data for the model are based on Version 6.0 of the GTAP database for 2001 together with data derived from other sources.

While it is likely that FTAs would be phased in over time for some products and sectors, it is assumed for modelling purposes that all of the barriers are removed at the same time. The model is then solved computationally to represent the percent changes in the variables of interest and to calculate the absolute changes in employment by sector. Because full employment is assumed, the employment results presented indicate the shifts in sectoral employment that will occur with FTA liberalisation. As indicated in the detailed sectoral tables in KMS (2008), some sectors will have increases in employment, others will have decreases, and there is no change in employment overall. Broadly speaking, the sectoral changes mirror the comparative advantages of the BRIICS countries in agricultural, natural resource and mineral products and in labour-intensive manufactures. The comparative advantages of Japan, EU/EFTA and the United States lie in capital-intensive manufactures and in services.

The unique feature of our study is that we have analysed the simultaneous removal of trade barriers for the BRIICS countries with a variety of FTA partners. The computational results presented thus reflect both the direct effects of the bilateral FTAs and the effects of the other postulated FTAs. It appears that the welfare effects of the different FTA options are for the most part fairly small in absolute terms and as a percentage of GDP. However, in a number of cases, the intersectoral shifts in output and employment are substantial, indicating a possible need for some sort of adjustment if the FTAs were actually carried out. The global results of the different FTA scenarios suggest some trade diversion for non-member countries but the welfare reductions are small.

There is no evidence from these results that China's is crowding-out other countries from global markets and reinforcing specialisation in raw materials in these countries. The computational results clearly show that while there may be significant sectoral shifts owing to freer trade, there are large potential benefits available for many countries.

To provide some perspective on the results of the FTAs, the model was also used to calculate the effects of unilateral tariff removal by the BRIICS countries and global (multilateral) free trade. Not surprisingly, these calculations suggest that much greater increases in economic welfare could be gained from more broadly based trade liberalisation than by negotiating FTAs. 


\section{References}

Brown, D. K. and R. M. Stern (1989a), Computational Analysis of the U.S.-Canadian Free Trade Agreement: The Role of Product Differentiation and Market Structure,” in R.C. Feenstra (ed.), Trade Policies for International Competitiveness. Chicago: University of Chicago Press.

Brown, D. K. and R. M. Stern (1989b), “Computable General Equilibrium Estimates of the Gains from U.S.-Canadian Trade Liberalisation,” in D. Greenaway, T. Hyclak, and R. J. Thornton (eds.), Economic Aspects of Regional Trading Arrangements, London: Harvester Wheatsheaf.

Brown, D.. K., A. V. Deardorff and R. M. Stern (2002), "CGE Modeling and Analysis of Multilateral and Regional Negotiating Options,” in R. M. Stern (ed.), Issues and Options for U.S.-Japan Trade Policies. Ann Arbor: University of Michigan Press.

Brown, D. K., A. V. Deardorff and R. M. Stern (2003), "Multilateral, Regional, and Bilateral Trade-Policy Options for the United States and Japan,” The World Economy 26(6): 803-828.

Council for Economic Planning and Development (2006), Taiwan Statistical Databook 2006. Taipei: R.O.C., Council for Economic Planning and Development.

Deardorff, A. V., and R. M. Stern (1990), Computational Analysis of Global Trading Arrangements. Ann Arbor: University of Michigan Press.

Dimaranan, B. V. and R. A. McDougall (2005), Global Trade, Assistance, and Protection: The GTAP 6 Data Base. West Lafayette, IN: Center for Global Trade Analysis, Purdue University.

Harrison, W. J. and K. Pearson (1996), "Computing Solutions for Large General Equilibrium Models using GEMPACK,” Computational Economics 9:83-127.

Hoekman, B. (1995), “Assessing the Agreement on Trade in Services," in Will Martin and L. Alan Winters (eds.), The Uruguay Round and the Developing Economies. Washington, D.C.: World Bank.

Hoekman, B. (2000), "The Next Round of Services Negotiations: Identifying Priorities and Options," Federal Reserve Bank of St. Louis Review, 82: 31-47.

International Labour Organisation (2006), LABORSTA [http://laborsta.ilo.org/cgi-bin/brokerv8. exe].

Kiyota, K., M. Molnar and R. M. Stern (2008), "Computational Analysis of Bilateral FTA Options for Selected Emerging Market Economies: Brazil, Russia, India, Indonesia, China, and South Africa,” OECD Trade Policy Working Paper, forthcoming.

Ministry of Home Affairs (2003), Census of India. New Delhi: Ministry of Home Affairs.

Stolper, W. and P. A. Samuelson (1941), "Protection and Real Wages,” Review of Economic Studies 9(1): 58-73. 
United Nations Industrial Development Organisation (UNIDO) (2006), Industrial Statistics Database, 3-digit Level of ISIC Code (Revision 2) on CD-ROM. Vienna, Austria: UNIDO.

Van den Mensbrugghe, D. (2005), Linkage Technical Reference Document, World Bank.

World Bank (2006), World Development Indicators on CD-ROM. Washington, D.C.: World Bank. 


\section{Annex: The Michigan model of world production and trade}

\section{Overview of the Michigan Model}

The version of the Michigan Model that we use in this study covers 27 economic sectors, including agriculture, manufactures, and services, in each of 31 countries/regions. The distinguishing feature of the Michigan Model is that it incorporates some aspects of trade with imperfect competition, including increasing returns to scale, monopolistic competition, and product variety. ${ }^{1}$ A more complete description of the formal structure and equations of the model can be found on line at www.Fordschool.umich.edu/rsie/model/. For the technical properties of the model, see Annex A.

\section{Sectors and market structure}

As mentioned, the version of the model to be used in this study consists of 27 production sectors and 31 countries/regions (plus rest-of-world). The sectoral and country/region coverage is indicated in the tables below. Agriculture is modelled as perfectly competitive with product differentiation by country of origin, and all other sectors covering manufactures and services are modelled as monopolistically competitive. Each monopolistically competitive firm is assumed to produce a differentiated product and to set price as a profit-maximising mark-up of price over marginal cost. Free entry and exit of firms then guarantees zero profits.

\section{Expenditure}

Consumers and producers are assumed to use a two-stage procedure to allocate expenditure across differentiated products. In the first stage, expenditure is allocated across goods without regard to the country of origin or producing firm. At this stage, the utility function is Cobb-Douglas, and the production function requires intermediate inputs in fixed proportions. In the second stage, expenditure on monopolistically competitive goods is allocated across the competing varieties supplied by each firm from all countries. In the perfectly competitive agricultural sector, since individual firm supply is indeterminate, expenditure is allocated over each country's sector as a whole, with imperfect substitution between products of different countries.

The aggregation function in the second stage is a Constant Elasticity of Substitution (CES) function. Use of the CES function and product differentiation by firm imply that consumer welfare is influenced both by any reduction in real prices brought about by trade liberalisation, as well as increased product variety. The elasticity of substitution among different varieties of a good is assumed to be three, a value that is broadly consistent with available empirical estimates. The parameter for the sensitivity of consumers to the number of product varieties is set at 0.5 .

$1 \quad$ See also Deardorff and Stern (1990, esp. pp. 9-46) and Brown and Stern (1989a, b).

2 If the variety parameter is greater than 0.5 , it means that consumers value variety more. If the parameter is zero, consumers have no preference for variety. This is the same as the Armington assumption according to which consumers view products as distinguished by country of production. 


\section{Production}

The production function is separated into two stages. In the first stage, intermediate inputs and a primary composite of capital and labour are used in fixed proportion to output. ${ }^{3}$ In the second stage, capital and labour are combined through a CES function to form the primary composite. In the monopolistically competitive sectors, additional fixed inputs of capital and labour are required. It is assumed that fixed capital and fixed labour are used in the same proportion as variable capital and variable labour so that production functions are homothetic. The elasticities of substitution between capital and labour vary across sectors and were derived from a literature search of empirical estimates of sectoral supply elasticities. Economies of scale are determined endogenously in the model.

\section{Supply prices}

To determine equilibrium prices, perfectly competitive firms operate such that price is equal to marginal cost, while monopolistically competitive firms maximise profits by setting price as an optimal mark-up over marginal cost. The numbers of firms in sectors under monopolistic competition are determined by the zero profits condition. The free entry condition in this context is also the basic mechanism through which new product varieties are created (or eliminated). Each of the new entrants arrives with a distinctly different product, expanding the array of goods available to consumers.

Free entry and exit are also the means through which countries are able to realise the specialisation gains from trade. In this connection, it can be noted that in the commonly used GTAP-type model based on nationally differentiated products and the so-called Armington assumption, production of a particular variety of a good cannot move from one country to another. In such a model, there are gains from exchange but no gains from specialisation. However, in the Michigan Model with differentiated products supplied by monopolistically competitive firms, production of a particular variety is internationally mobile. A decline in the number of firms in one country paired with an expansion in another essentially implies that production of one variety of a good is being relocated from the country in which the number of firms is declining to the country in which the number of firms is expanding. Thus, we have both an exchange gain and a specialisation gain from international trade. ${ }^{4}$

\section{Capital and labour markets}

Capital and labour are assumed to be perfectly mobile across sectors within each country. Returns to capital and labour are determined so as to equate factor demand to an exogenous supply of each factor. The aggregate supplies of capital and labour in each country are assumed to remain fixed so as to abstract from macroeconomic considerations (e.g. the determination of investment), since our microeconomic focus is on the inter-sectoral allocation of resources.

Intermediate inputs include both domestic and imported varieties.

The international relocation of a particular variety of a good can be understood in the context of the ongoing outsourcing debate. Domestic firms require intermediate inputs, in addition to capital and labour. To the extent that tariff reduction leads a firm to substitute toward traded intermediate inputs, domestic firms can be thought of as outsourcing some component of production. This is particularly the case if there is a decline in the number of domestic firms in the sector from which intermediate inputs are purchased and an expansion in the supplier country. 


\section{World market and trade balance}

The world market determines equilibrium prices such that all markets clear. Total demand for each firm or sector's product must equal total supply of that product. It is also assumed that trade remains balanced for each country/region, that is, any initial trade imbalance remains constant as trade barriers are changed. This is accomplished by permitting aggregate expenditure to adjust to maintain a constant trade balance. Thus, we abstract away from the macroeconomic forces and policies that are the main determinants of trade imbalances. Further, it should be noted that there are no nominal rigidities in the model. As a consequence, there is no role for a real exchange rate mechanism.

\section{Trade policies and rent/revenues}

We have incorporated into the model the import tariff rates and export taxes/subsidies as policy inputs that are applicable to the bilateral trade of the various countries/regions with respect to one another. These have been computed using the "GTAP-6.0 2001 Database" provided in Dimaranan and McDougall (2005). The export barriers have been estimated as export-tax equivalents. ${ }^{5}$ We assume that revenues from both import tariffs and export taxes, as well as rents from NTBs on exports, are redistributed to consumers in the tariff- or tax-levying country and are spent like any other income.

Tariff liberalisation can affect economic efficiency through three main channels. First, in the context of standard trade theory, tariff reductions both reduce the cost of imports for consumers and for producers purchasing traded intermediate inputs, thus producing an exchange gain. Second, tariff removal leads firms to direct resources toward those sectors that have the greatest value on the world market. That is, we have the standard specialisation gain. Third, tariff reductions have a pro-competitive effect on sellers. Increased price pressure from imported varieties forces incumbent firms to cut price. Surviving firms remain viable by expanding output, thereby moving down their average total cost (ATC) curve. The consequent lower ATC of production creates gains from the realisation of economies of scale.

\section{Model closure and implementation}

We assume in the model that aggregate expenditure varies endogenously to hold aggregate employment constant. This closure is analogous to the Johansen closure rule (Deardorff and Stern, 1990, pp. 27-29). The Johansen closure rule consists of keeping the requirement of full employment while dropping the consumption function. This means that consumption can be thought of as adjusting endogenously to ensure full employment. However, in the present model, we do not distinguish consumption from other sources of final demand. That is, we assume instead that total expenditure adjusts to maintain full employment.

The model is solved using GEMPACK (Harrison and Pearson, 1996). With the introduction of policy changes into the model, the method of solution yields percentage changes in sectoral employment and certain other variables of interest. Multiplying the percentage changes by the absolute levels of the pertinent variables in the database yields the absolute changes, positive or negative, which might result from the various liberalisation scenarios.

$5 \quad$ Export tax equivalent includes the export quotas on textiles and clothing (wearing apparel) exports under the Agreement on Textiles and Clothing (ATC). For more detail about the protection data in GTAP-6.0 2001 Database, See Dimaranan and McDougall (2005, Section 16). 


\section{Interpreting the modelling results}

To help the reader interpret the modelling results, it is useful to review the features of the model that serve to identify the various economic effects to be reflected in the different applications of the model. Although the model includes the aforementioned features of imperfect competition, it remains the case that markets respond to trade liberalisation in much the same way that they would with perfect competition. That is, when tariffs or other trade barriers are reduced in a sector, domestic buyers (both final and intermediate) substitute toward imports and the domestic competing industry contracts production while foreign exporters expand. Thus, in the case of multilateral liberalisation that reduces tariffs and other trade barriers simultaneously in most sectors and countries, each country's industries share in both of these effects, expanding or contracting depending primarily on whether their protection is reduced more or less than in other sectors and countries.

Worldwide, these changes cause increased international demand for all sectors. World prices increase most for those sectors where trade barriers fall the most. ${ }^{6}$ This in turn causes changes in countries' terms of trade that can be positive or negative. Those countries that are net exporters of goods with the greatest degree of liberalisation will experience increases in their terms of trade, as the world prices of their exports rise relative to their imports. The reverse occurs for net exporters in industries where liberalisation is slight - perhaps because it may already have taken place in previous trade rounds.

The effects on the welfare of countries arise from a mixture of these terms-of-trade effects, together with the standard efficiency gains from trade and also from additional benefits due to the realisation of economies of scale. Thus, we expect on average that the world will gain from multilateral liberalisation, as resources are reallocated to those sectors in each country where there is a comparative advantage. In the absence of terms-of-trade effects, these efficiency gains should raise national welfare measured by the equivalent variation for every country, ${ }^{7}$ although some factor owners within a country may lose, as will be noted below. However, it is possible for a particular country whose net imports are concentrated in sectors with the greatest liberalisation to lose overall, if the worsening of its terms of trade swamps these efficiency gains.

On the other hand, although trade with imperfect competition is perhaps best known for introducing reasons why countries may lose from trade, actually its greatest contribution is to expand the list of reasons for gains from trade. Thus, in the Michigan Model, trade liberalisation permits all countries to expand their export sectors at the same time that all sectors compete more closely with a larger number of competing varieties from abroad. As a result, countries as a whole gain from lower costs due to increasing returns to scale, lower monopoly distortions due to greater competition, and reduced costs and/or increased utility due to greater product variety. All of these effects make it more likely that countries will gain from liberalisation in ways that are shared across the entire population. ${ }^{8}$

6 The price of agricultural products supplied by the rest of the world is taken as the numeraire in the model, and there is a rest-of-world against which all other prices can rise.

7 The equivalent variation is a measure of the amount of income that would have to be given or taken away from an economy before a change in policy in order to leave the economy as well off as it would be after the policy change has taken place. If the equivalent variation is positive, it is indicative of an improvement in economic welfare resulting from the policy change.

8 In perfectly competitive trade models such as the Heckscher-Ohlin Model, one expects countries as a whole to gain from trade, but the owners of one factor - the "scarce factor" - to lose through the mechanism first explored by Stolper and Samuelson (1941). The additional sources of gain from trade due to increasing returns to scale, competition, and product variety, however, are shared across factors, and we routinely find 
The various effects just described in the context of multilateral trade liberalisation will also take place when there is unilateral trade liberalisation, although these effects will depend on the magnitudes of the liberalisation in relation to the patterns of trade and the price and output responses involved between the liberalising country and its trading partners. Similarly, many of the effects described will take place with the formation of bilateral or regional FTAs, which are the focus of the present study. But in these cases, there may be trade creation and positive effects on the economic welfare of FTA-member countries together with trade diversion and negative effects on the economic welfare of non-member countries. The net effects on economic welfare for individual countries and globally will thus depend on the economic circumstances and policy changes implemented. ${ }^{9}$

In the real world, all of the various effects occur over time, some of them more quickly than others. However, the Michigan Model is static in the sense that it is based upon a single set of equilibrium conditions rather than relationships that vary over time. ${ }^{10}$ The model results therefore refer to a time horizon that depends on the assumptions made about which variables do and do not adjust to changing market conditions, and on the short- or long-run nature of these adjustments. ${ }^{11}$ Because the supply and demand elasticities used in the model reflect relatively long-run adjustments and it is assumed that markets for both labour and capital clear within countries, ${ }^{12}$ the modelling results are appropriate for a relatively long time horizon of several years - perhaps two or three at a minimum. On the other hand, the model does not allow for the very long-run adjustments that could occur through capital accumulation, population growth, and technological change. The modelling results should therefore be interpreted as

in our CGE modelling that both labour and capital gain from multilateral trade liberalisation.

$9 \quad$ It may be noted that, in a model of perfect competition, bilateral trade liberalisation should have the effect of contracting trade with the excluded countries, thereby improving the terms of trade for the FTA members vis-à-vis the rest of world. But in a model with scale economies, the pro-competitive effect of trade liberalisation can generate a cut in price and increase in supply to excluded countries. The terms of trade of FTA members may therefore deteriorate in this event.

10 As noted above, macroeconomic closure in the model involves the equivalent of having expenditure equal to the sum of earned incomes plus redistributed net tax revenues. However, the actual solution is attained indirectly, but equivalently, by imposing a zero change in the trade balance. Since the model allows for all net tax and tariff revenues to be redistributed to consumers, when tariffs are reduced with trade liberalisation, the model implicitly imposes a non-distorting tax to recoup the loss in tariff revenues.

11 It is important to understand that CGE modelling simulation results provide indications of the potential economic changes involved. In this respect, they are not meant to be empirical forecasts or predictions of the changes since they are not derived from econometric methods that can yield statistically-based estimations. Further, because they are microeconomic in character, CGE models of necessity abstract from the macroeconomic forces at work at the aggregate level in individual countries. As a consequence, it may be very difficult to compare CGE modelling results with the actual changes that occur in the economic variables over given periods of time. A further important consideration is that CGE models used to analyse the effects of trade liberalisation may differ because of the assumptions that characterise their framework. In any event, CGE modelling results are therefore to be interpreted as the potential effects of trade liberalisation at the microeconomic level, holding macroeconomic influences constant. The magnitudes and directions of change indicated by the CGE models are thus very useful in their own right, subject to the caveats just mentioned.

12 The analysis in the model assumes throughout that the aggregate, economy-wide, level of employment is held constant in each country. The effects of trade liberalisation are therefore not permitted to change any country's overall rates of employment or unemployment. This assumption is made because overall employment is determined by macroeconomic forces and policies that are not contained in the model and would not themselves be included in a negotiated trade agreement. The focus instead is on the composition of employment across sectors as determined by the microeconomic interactions of supply and demand resulting from the liberalisation of trade. 
- CHAPTER 5: STORM IN A SPAGHETTI BOWL: FTA’S AND THE BRIICS

being superimposed upon longer-run growth paths of the economies involved. To the extent that these growth paths themselves may be influenced by trade liberalisation, therefore, the model does not capture such effects.

\section{Benchmark Data}

Needless to say, the data needs of this model are immense. Apart from numerous share parameters, the model requires various types of elasticity measures. Like other CGE models, most of our data come from published sources.

The main data source used in the model is "The GTAP-6.0 Database" of the Purdue University Center for Global Trade Analysis Project (Dimaranan and McDougall, 2005). The reference year for this GTAP database is 2001. From this source, we have extracted the following data, aggregated to our sectors and countries/regions:

- Bilateral trade flows among 31 countries/regions, decomposed into 27 sectors. Trade with the rest-of-world (ROW) is included to close the model.

- Input-output tables for the 31 countries/regions, excluding ROW.

- Components of final demand along with sectoral contributions for the 31 countries/regions, excluding ROW.

- Gross value of output and value added at the sectoral level for the 31 countries/regions, excluding ROW

- Bilateral import tariffs by sector among the 31 countries/regions.

- Elasticity of substitution between capital and labour by sector.

- Bilateral export-tax equivalents among the 31 countries/regions, decomposed into 27 sectors.

The monopolistically competitive market structure in the non-agricultural sectors of the model imposes an additional data requirement of employment and the numbers of firms at the sectoral level. These data have been adapted from a variety of published sources as will be noted below.

The GTAP-6.0 2001 database has been projected to the year 2020, which is when we assume that the Doha Round will have been completed and fully implemented. In this connection, we extrapolated the labour availability in different countries/regions by an annual-average, weighted-population growth rate that varies by country/region. ${ }^{13}$ All other major variables have been projected, using an average weighted growth rate of GDP of $3.1 \%$. In the computational scenarios to be presented below, we use these extrapolated data as the starting point to carry out our liberalisation scenarios for the various BRIICS FTAs and for the accompanying unilateral and global free trade scenarios.

In the GTAP-6.0 2001 database, the barriers on agricultural products consist of import tariffs, export subsidies/taxes, and domestic support. Tariffs on food and agriculture come from the Agricultural Trade Policy Database of the Economic Research Service in the US Department of Agriculture. Domestic

13 The growth projection of labour force from 2001 to 2020 is obtained from U.S. Census Bureau, IDB Summary Demographic Data for Taiwan and United Nations, World Population Prospects (The 2004 Revision, medium variant, http://esa.un.org/unpp) for other countries/regions. For a more elaborate and detailed procedure for calculating data extrapolations, see van der Mensbrugghe (2005) and related documents. 
support data are based on the producer support estimates for OECD countries and input-output tables for non-OECD countries if data are available. Tariffs on merchandise come from the World Integrated Trade Solutions system of the World Bank and UNCTAD. To incorporate the implementation of the Doha Round, the GTAP-6.0 2001 database has been adjusted using the tariff-cutting scenario provided by GTAP. ${ }^{14}$ The assumed implementation of the Doha Round means that developed countries will cut agricultural protection by the percentages specified in the Doha Development Agenda, and all countries are assumed to adopt $50 \%$ tariff cuts for non-agricultural goods and manufactures.

The services barriers are based on financial data on average gross (price-cost) margins constructed initially by Hoekman (1995, 2000) and adapted for modelling purposes in Brown, Deardorff, and Stern (2002, 2003). The gross operating margins are calculated as the differences between total revenues and total operating costs and are presumed to reflect the barriers on the various modes of services transactions. Some of these differences are presumably attributable to fixed costs. Given that the gross operating margins vary across countries, a portion of the margin can be attributed in particular to barriers to FDI. For this purpose, a benchmark is set for each sector in relation to the country with the smallest gross operating margin, on the assumption that operations in the benchmark country can be considered to be freely open to foreign firms. The excess in any other country above this lowest benchmark is then taken to be due to barriers to establishment by foreign firms.

That is, the barrier is modelled as the cost-increase attributable to an increase in fixed cost borne by multinational corporations attempting to establish an enterprise locally in a host country. This abstracts from the possibility that fixed costs may differ among firms because of variations in market size, distance from headquarters, and other factors. It is further assumed that this cost increase can be interpreted as an ad valorem equivalent tariff on services transactions generally. The services barriers based on Hoekman (2000) are considerably higher than the import barriers on manufactures and reflect the fact that many services sectors are highly regulated and therefore may restrain international services transactions considerably. Nonetheless, as noted, because of the variations that exist in fixed costs, it is possible that the Hoekman services barriers may be overstated. We have accordingly reduced these barriers by $50 \%$ for modelling purposes.

Employment data, defined as labour force $\left(L F_{i}\right)$, were obtained from Ministry of Home Affairs (2003) for India, Council for Economic Planning and Development (2006) for Chinese Taipei, and World Bank (2006) for other countries or regions. Since employment data are not available at the sectoral level, we estimated the sectoral employment share $s_{i j}$, using the latest available data from UNIDO (2006) for manufacturing and from ILO (2006) for non-manufacturing sectors. Multiplying the share by the total labour force (i.e. $L F_{i} \times s_{i j}$ ), we estimated the sectoral employment data. Employment in the agricultural sector was further decomposed into 10 detailed agricultural sectors, using the labour endowment data in the GTAP-6.0 2001 database (i.e. the employment was decomposed by the labour endowment shares).

Data on the number of firms were obtained from UNIDO (2006). If the number of firms was not available, we used the data for the number of establishments. Since the latest available years are different among countries and regions, we adjusted the number of firms, using the per-capita GDP growth rate. For instance, if the latest available year was 2000, we multiplied the per-capita GDP growth rate from 2000 to 2001 by the number of firms. When the number of firms was not available, we first estimated the total number of firms in the manufacturing sectors and then decomposed this total to the sectoral level, using the sectoral employment shares. In some cases, the total number of firms was estimated from the number of firms and the relative per capita GDP in comparable, neighbouring countries.

14 For more detail, see https://www.gtap.agecon.purdue.edu/databases/v6/V6_dohascen.asp 
CHAPTER 5: STORM IN A SPAGHETTI BOWL: FTA'S AND THE BRIICS

The sectoral data for the individual BRIICS economies that we have used for our modelling purposes are recorded in BKS (2008, Tables 1-6). These data cover the Post-Doha Round tariff rates on agricultural and natural resource products and manufactures, tariff equivalents on services, the values and percentage distribution of exports and imports for the world and the OECD countries, and employment. 


\section{Annex Tables}

\section{Annex Table 5A.1. Scenarios}

\begin{tabular}{|c|c|}
\hline & Country pairs \\
\hline Scenario 1 & $\begin{array}{l}\text { 1) Brazil - United States; 2) Russia - European Union; 3) India - Japan; 4) AFTA; 5) Indonesia - Japan; 6) China - Japan; 7) South Africa - } \\
\text { European Union }\end{array}$ \\
\hline Scenario 2 & $\begin{array}{l}\text { 1) Brazil - United States; 2) Brazil - European Union; 3) Russia - European Union; 4) India - Japan; 5) India - United States; 6) AFTA; 7) } \\
\text { Indonesia - Japan; 8) Indonesia - United States; 9) China - Japan; 10) South Africa - European Union }\end{array}$ \\
\hline Scenario 3 & $\begin{array}{l}\text { 1) Brazil - United States; 2) Brazil - European Union; 3) Russia - European Union; 4) India - Japan; 5) India - United States; 6) AFTA; 7) } \\
\text { Indonesia - Japan; 8) Indonesia - United States; 9) Indonesia - China; 10) China - Japan; 11) South Africa - European Union }\end{array}$ \\
\hline Scenario 4 & $\begin{array}{l}\text { 1) Brazil - United States; 2) Brazil - European Union; 3) Russia - European Union; 4) India - Japan; 5) India - United States; 6) India - } \\
\text { ASEAN; 7) AFTA; 8) Indonesia - Japan; 9) Indonesia - United States; 10) Indonesia - China; 11) China - Japan; 12) China - ASEAN; 13) } \\
\text { South Africa - European Union }\end{array}$ \\
\hline Scenario 5 & $\begin{array}{l}\text { 1) Brazil - United States; 2) Brazil - European Union; 3) Russia - European Union; 4) India - Japan; 5) India - United States; 6) India - } \\
\text { ASEAN; 7) India-China; 8) AFTA; 9) Indonesia - Japan; 10) Indonesia - United States; 11) Indonesia - China; 12) China - Japan; 13) } \\
\text { China - ASEAN; 14) South Africa - European Union }\end{array}$ \\
\hline
\end{tabular}

\section{Annex Table 5A.2. Scenario 1 - Global Welfare Effects of BRIICS Free Trade Agreements}

(billions of U.S. dollars and percentage)

\begin{tabular}{|c|c|c|c|c|c|c|c|c|c|c|c|c|c|c|}
\hline \multirow{3}{*}{$\begin{array}{lc} & \text { Home } \\
& \text { Partner } \\
& \\
\text { Japan } & \end{array}$} & \multicolumn{2}{|c|}{$\begin{array}{l}\text { Brazil } \\
\text { US } \\
\text { Welfare }\end{array}$} & \multicolumn{2}{|c|}{$\begin{array}{l}\text { Russia } \\
\text { EU } \\
\text { Welfare }\end{array}$} & \multicolumn{2}{|c|}{$\begin{array}{c}\text { India } \\
\text { Japan } \\
\text { Welfare }\end{array}$} & \multicolumn{2}{|c|}{$\begin{array}{c}\text { Indonesia } \\
\text { ASEAN, Japan } \\
\text { Welfare }\end{array}$} & \multicolumn{2}{|c|}{$\begin{array}{l}\text { China } \\
\text { Japan } \\
\text { Welfare }\end{array}$} & \multicolumn{2}{|c|}{$\begin{array}{c}\text { South Africa } \\
\text { EU } \\
\text { Welfare }\end{array}$} & \multicolumn{2}{|c|}{$\begin{array}{c}\text { Scenario } 1 \\
\text { Welfare }\end{array}$} \\
\hline & U.S.\$ & $\%$ of GDP & U.S.\$ & $\%$ of GDP & U.S.\$ & $\%$ of GDP & U.S.\$ & $\%$ of GDP & U.S.\$ & $\%$ of GDP & U.S.\$ & $\%$ of GDP & U.S.\$ & $\%$ of GDP \\
\hline & 0.1 & 0.0 & 0.7 & 0.0 & 7.1 & 0.1 & 4.7 & 0.1 & 45.8 & 0.6 & -0.1 & 0.0 & 58.2 & 0.8 \\
\hline United States & 20.4 & 0.1 & 2.3 & 0.0 & 0.4 & 0.0 & 0.9 & 0.0 & 1.1 & 0.0 & 0.4 & 0.0 & 25.5 & 0.1 \\
\hline Canada & 0.4 & 0.0 & 0.0 & 0.0 & 0.1 & 0.0 & 0.0 & 0.0 & 0.2 & 0.0 & 0.0 & 0.0 & 0.6 & 0.0 \\
\hline Australia & 0.0 & 0.0 & 0.0 & 0.0 & 0.0 & 0.0 & 0.2 & 0.0 & 0.3 & 0.1 & 0.0 & 0.0 & 0.5 & 0.1 \\
\hline New Zealand & 0.0 & 0.0 & 0.0 & 0.0 & 0.0 & 0.0 & 0.0 & 0.0 & 0.0 & 0.1 & 0.0 & 0.0 & 0.1 & 0.1 \\
\hline EU and EFTA & -0.2 & 0.0 & 39.0 & 0.3 & 0.4 & 0.0 & 0.4 & 0.0 & 0.2 & 0.0 & 12.0 & 0.1 & 51.6 & 0.3 \\
\hline China & 0.3 & 0.0 & 0.6 & 0.0 & 0.0 & 0.0 & 0.1 & 0.0 & -1.7 & -0.1 & 0.0 & 0.0 & -0.7 & 0.0 \\
\hline Hong Kong & 0.1 & 0.0 & 0.1 & 0.0 & 0.0 & 0.0 & 0.2 & 0.1 & -0.3 & -0.1 & 0.0 & 0.0 & 0.1 & 0.0 \\
\hline Indonesia & 0.0 & 0.0 & 0.0 & 0.0 & 0.0 & 0.0 & 4.5 & 1.8 & -0.1 & 0.0 & 0.0 & 0.0 & 4.4 & 1.7 \\
\hline Korea & 0.0 & 0.0 & 0.0 & 0.0 & 0.0 & 0.0 & -0.2 & 0.0 & -0.6 & -0.1 & 0.0 & 0.0 & -0.9 & -0.1 \\
\hline Malaysia & 0.0 & 0.0 & 0.0 & 0.0 & 0.0 & 0.0 & 3.9 & 2.5 & -0.3 & -0.2 & 0.0 & 0.0 & 3.5 & 2.3 \\
\hline Philippines & 0.0 & 0.0 & 0.0 & 0.0 & 0.0 & 0.0 & 1.9 & 1.5 & 0.0 & 0.0 & 0.0 & 0.0 & 1.9 & 1.5 \\
\hline Singapore & 0.0 & 0.0 & 0.1 & 0.1 & 0.0 & 0.0 & 2.6 & 1.9 & -0.1 & -0.1 & 0.0 & 0.0 & 2.7 & 1.9 \\
\hline Taiwan & 0.0 & 0.0 & 0.1 & 0.0 & 0.0 & 0.0 & 0.0 & 0.0 & -0.7 & -0.2 & 0.0 & 0.0 & -0.7 & -0.1 \\
\hline Thailand & 0.0 & 0.0 & 0.1 & 0.0 & 0.0 & 0.0 & 3.2 & 1.6 & -0.2 & -0.1 & 0.0 & 0.0 & 3.1 & 1.5 \\
\hline Vietnam & 0.0 & 0.0 & 0.0 & 0.1 & 0.0 & 0.0 & 0.6 & 1.0 & -0.1 & -0.1 & 0.0 & 0.0 & 0.5 & 0.9 \\
\hline India & 0.0 & 0.0 & 0.0 & 0.0 & 2.1 & 0.2 & 0.1 & 0.0 & -0.1 & 0.0 & 0.0 & 0.0 & 2.1 & 0.2 \\
\hline Rest of Asia & 0.0 & 0.0 & 0.1 & 0.0 & 0.0 & 0.0 & 0.3 & 0.1 & -0.1 & 0.0 & 0.0 & 0.0 & 0.3 & 0.1 \\
\hline Russia & -0.1 & 0.0 & 11.6 & 2.1 & 0.0 & 0.0 & 0.0 & 0.0 & 0.0 & 0.0 & 0.0 & 0.0 & 11.5 & 2.1 \\
\hline Turkey & 0.0 & 0.0 & 0.3 & 0.1 & 0.0 & 0.0 & 0.1 & 0.0 & 0.0 & 0.0 & 0.0 & 0.0 & 0.4 & 0.1 \\
\hline Rest of Middle East & 0.0 & 0.0 & 0.2 & 0.0 & 0.0 & 0.0 & 1.0 & 0.1 & 0.3 & 0.0 & 0.0 & 0.0 & 1.5 & 0.1 \\
\hline Mexico & 0.3 & 0.0 & 0.0 & 0.0 & 0.0 & 0.0 & 0.0 & 0.0 & 0.1 & 0.0 & 0.0 & 0.0 & 0.4 & 0.0 \\
\hline Argentina & -0.5 & -0.1 & 0.0 & 0.0 & 0.0 & 0.0 & 0.0 & 0.0 & 0.0 & 0.0 & 0.0 & 0.0 & -0.5 & -0.1 \\
\hline Brazil & 2.4 & 0.3 & 0.0 & 0.0 & 0.0 & 0.0 & 0.0 & 0.0 & 0.0 & 0.0 & -0.1 & 0.0 & 2.4 & 0.3 \\
\hline Chile & 0.0 & 0.0 & 0.0 & 0.0 & 0.0 & 0.0 & 0.0 & 0.0 & 0.1 & 0.1 & 0.0 & 0.0 & 0.1 & 0.1 \\
\hline Colombia & 0.0 & 0.0 & 0.0 & 0.0 & 0.0 & 0.0 & 0.0 & 0.0 & 0.0 & 0.0 & 0.0 & 0.0 & 0.0 & 0.1 \\
\hline Peru & 0.0 & 0.0 & 0.0 & 0.0 & 0.0 & 0.0 & 0.0 & 0.0 & 0.0 & 0.0 & 0.0 & 0.0 & 0.0 & 0.0 \\
\hline Uruguay & 0.0 & -0.1 & 0.0 & 0.0 & 0.0 & 0.0 & 0.0 & 0.0 & 0.0 & 0.0 & 0.0 & 0.0 & 0.0 & 0.0 \\
\hline Rest of Central and Latin America & 0.1 & 0.0 & 0.2 & 0.0 & 0.0 & 0.0 & 0.1 & 0.0 & 0.1 & 0.0 & 0.0 & 0.0 & 0.5 & 0.1 \\
\hline South Africa & 0.0 & 0.0 & -0.1 & 0.0 & 0.0 & 0.0 & 0.0 & 0.0 & 0.1 & 0.1 & 2.6 & 1.3 & 2.7 & 1.3 \\
\hline Africa & 0.0 & 0.0 & 0.0 & 0.0 & 0.0 & 0.0 & 0.2 & 0.0 & 0.1 & 0.0 & 0.1 & 0.0 & 0.4 & 0.0 \\
\hline Total & 23.3 & & 55.3 & & 10.2 & & 24.5 & & 43.9 & & 15.0 & & 172.2 & \\
\hline
\end{tabular}


20 - CHAPTER 5: STORM IN A SPAGHETTI BOWL: FTA'S AND THE BRIICS

Annex Table 5A.3. Scenario 2 - Global Welfare Effects of BRIICS Free Trade Agreements

(billions of U.S. dollars and percentage)

\begin{tabular}{|c|c|c|c|c|c|c|c|c|c|c|c|c|c|c|}
\hline \multirow[t]{3}{*}{$\begin{array}{l}\text { Home } \\
\text { Partner }\end{array}$} & \multicolumn{2}{|c|}{$\begin{array}{l}\text { Brazil } \\
\text { US, EU } \\
\text { Welfare }\end{array}$} & \multicolumn{2}{|c|}{$\begin{array}{l}\text { Russia } \\
\text { EU } \\
\text { Welfare }\end{array}$} & \multicolumn{2}{|c|}{$\begin{array}{l}\text { India } \\
\text { Japan, US } \\
\text { Welfare }\end{array}$} & \multicolumn{2}{|c|}{$\begin{array}{c}\text { Indonesia } \\
\text { ASEAN, Japan, US } \\
\text { Welfare }\end{array}$} & \multicolumn{2}{|c|}{$\begin{array}{l}\text { China } \\
\text { Japan } \\
\text { Welfare }\end{array}$} & \multicolumn{2}{|c|}{$\begin{array}{c}\text { South Africa } \\
\text { EU } \\
\text { Welfare }\end{array}$} & \multicolumn{2}{|c|}{$\begin{array}{c}\text { Scenario } 2 \\
\text { Welfare }\end{array}$} \\
\hline & U.S.\$ & $\%$ of GDP & U.S.\$ & $\%$ of GDP & U.S. $\$$ & $\%$ of GDP & U.S.\$ & $\%$ of GDP & U.S.\$ & $\%$ of GDP & U.S.\$ & $\%$ of GDP & U.S.\$ & $\%$ of GDP \\
\hline & 0.1 & 0.0 & 0.7 & 0.0 & 7.2 & 0.1 & 4.3 & 0.1 & 45.8 & 0.6 & -0.1 & 0.0 & 57.8 & 0.8 \\
\hline United States & 20.5 & 0.1 & 2.3 & 0.0 & 16.1 & 0.1 & 8.2 & 0.1 & 1.1 & 0.0 & 0.4 & 0.0 & 48.6 & 0.3 \\
\hline Canada & 0.3 & 0.0 & 0.0 & 0.0 & 0.3 & 0.0 & 0.0 & 0.0 & 0.2 & 0.0 & 0.0 & 0.0 & 0.8 & 0.1 \\
\hline Australia & 0.0 & 0.0 & 0.0 & 0.0 & 0.0 & 0.0 & 0.2 & 0.0 & 0.3 & 0.1 & 0.0 & 0.0 & 0.6 & 0.1 \\
\hline New Zealand & 0.0 & 0.0 & 0.0 & 0.0 & 0.0 & 0.0 & 0.0 & 0.0 & 0.0 & 0.1 & 0.0 & 0.0 & 0.1 & 0.1 \\
\hline EU and EFTA & 33.5 & 0.2 & 39.0 & 0.3 & 0.7 & 0.0 & 0.5 & 0.0 & 0.2 & 0.0 & 12.0 & 0.1 & 85.8 & 0.6 \\
\hline China & 0.5 & 0.0 & 0.6 & 0.0 & 0.0 & 0.0 & 0.2 & 0.0 & -1.7 & -0.1 & 0.0 & 0.0 & -0.5 & 0.0 \\
\hline Hong Kong & 0.1 & 0.1 & 0.1 & 0.0 & 0.0 & 0.0 & 0.2 & 0.1 & -0.3 & -0.1 & 0.0 & 0.0 & 0.1 & 0.1 \\
\hline Indonesia & 0.0 & 0.0 & 0.0 & 0.0 & 0.0 & 0.0 & 8.8 & 3.4 & -0.1 & 0.0 & 0.0 & 0.0 & 8.6 & 3.3 \\
\hline Korea & -0.1 & 0.0 & 0.0 & 0.0 & 0.0 & 0.0 & -0.4 & -0.1 & -0.6 & -0.1 & 0.0 & 0.0 & -1.0 & -0.1 \\
\hline Malaysia & 0.0 & 0.0 & 0.0 & 0.0 & 0.0 & 0.0 & 3.7 & 2.4 & -0.3 & -0.2 & 0.0 & 0.0 & 3.3 & 2.2 \\
\hline Philippines & 0.0 & 0.0 & 0.0 & 0.0 & 0.0 & 0.0 & 1.8 & 1.4 & 0.0 & 0.0 & 0.0 & 0.0 & 1.8 & 1.5 \\
\hline Singapore & 0.0 & 0.0 & 0.1 & 0.1 & 0.0 & 0.0 & 2.6 & 1.8 & -0.1 & -0.1 & 0.0 & 0.0 & 2.7 & 1.9 \\
\hline Taiwan & 0.0 & 0.0 & 0.1 & 0.0 & 0.0 & 0.0 & -0.2 & 0.0 & -0.7 & -0.2 & 0.0 & 0.0 & -0.8 & -0.2 \\
\hline Thailand & 0.1 & 0.0 & 0.1 & 0.0 & 0.0 & 0.0 & 3.1 & 1.5 & -0.2 & -0.1 & 0.0 & 0.0 & 3.0 & 1.5 \\
\hline Vietnam & 0.0 & 0.0 & 0.0 & 0.1 & 0.0 & 0.0 & 0.6 & 1.0 & -0.1 & -0.1 & 0.0 & 0.0 & 0.5 & 0.9 \\
\hline India & 0.1 & 0.0 & 0.0 & 0.0 & 8.1 & 1.0 & -0.1 & 0.0 & -0.1 & 0.0 & 0.0 & 0.0 & 8.1 & 1.0 \\
\hline Rest of Asia & 0.1 & 0.0 & 0.1 & 0.0 & 0.0 & 0.0 & 0.2 & 0.0 & -0.1 & 0.0 & 0.0 & 0.0 & 0.3 & 0.1 \\
\hline Russia & 0.2 & 0.0 & 11.6 & 2.1 & 0.0 & 0.0 & 0.0 & 0.0 & 0.0 & 0.0 & 0.0 & 0.0 & 11.8 & 2.2 \\
\hline Turkey & 0.1 & 0.0 & 0.3 & 0.1 & 0.0 & 0.0 & 0.0 & 0.0 & 0.0 & 0.0 & 0.0 & 0.0 & 0.4 & 0.2 \\
\hline Rest of Middle East & 0.1 & 0.0 & 0.2 & 0.0 & 0.0 & 0.0 & 1.4 & 0.1 & 0.3 & 0.0 & 0.0 & 0.0 & 2.0 & 0.2 \\
\hline Mexico & 0.3 & 0.0 & 0.0 & 0.0 & 0.1 & 0.0 & 0.0 & 0.0 & 0.1 & 0.0 & 0.0 & 0.0 & 0.5 & 0.1 \\
\hline Argentina & -1.2 & -0.3 & 0.0 & 0.0 & 0.0 & 0.0 & 0.0 & 0.0 & 0.0 & 0.0 & 0.0 & 0.0 & -1.2 & -0.3 \\
\hline Brazil & 6.4 & 0.7 & 0.0 & 0.0 & 0.0 & 0.0 & 0.0 & 0.0 & 0.0 & 0.0 & -0.1 & 0.0 & 6.4 & 0.7 \\
\hline Chile & 0.1 & 0.1 & 0.0 & 0.0 & 0.0 & 0.0 & 0.0 & 0.0 & 0.1 & 0.1 & 0.0 & 0.0 & 0.2 & 0.2 \\
\hline Colombia & 0.0 & 0.0 & 0.0 & 0.0 & 0.0 & 0.0 & 0.0 & 0.0 & 0.0 & 0.0 & 0.0 & 0.0 & 0.1 & 0.1 \\
\hline Peru & 0.0 & 0.0 & 0.0 & 0.0 & 0.0 & 0.0 & 0.0 & 0.0 & 0.0 & 0.0 & 0.0 & 0.0 & 0.0 & 0.0 \\
\hline Uruguay & 0.0 & -0.1 & 0.0 & 0.0 & 0.0 & 0.0 & 0.0 & 0.0 & 0.0 & 0.0 & 0.0 & 0.0 & 0.0 & -0.1 \\
\hline Rest of Central and Latin America & 0.2 & 0.0 & 0.2 & 0.0 & 0.0 & 0.0 & 0.1 & 0.0 & 0.1 & 0.0 & 0.0 & 0.0 & 0.6 & 0.1 \\
\hline South Africa & 0.1 & 0.0 & -0.1 & 0.0 & 0.0 & 0.0 & 0.1 & 0.0 & 0.1 & 0.1 & 2.6 & 1.3 & 2.7 & 1.4 \\
\hline Africa & 0.3 & 0.0 & 0.0 & 0.0 & 0.0 & 0.0 & 0.2 & 0.0 & 0.1 & 0.0 & 0.1 & 0.0 & 0.7 & 0.1 \\
\hline Total & 61.9 & & 55.3 & & 32.5 & & 35.4 & & 43.9 & & 15.0 & & 244.0 & \\
\hline
\end{tabular}

Annex Table 5A.4. Scenario 3 - Global Welfare Effects of BRIICS Free Trade Agreements

(billions of U.S. dollars and percentage)

\begin{tabular}{|c|c|c|c|c|c|c|c|c|c|c|c|c|c|c|}
\hline \multirow[t]{2}{*}{$\begin{array}{l}\text { Home } \\
\text { Partner }\end{array}$} & \multicolumn{2}{|c|}{$\begin{array}{l}\text { Brazil } \\
\text { US, EU } \\
\text { Welfare }\end{array}$} & \multicolumn{2}{|c|}{$\begin{array}{c}\text { Russia } \\
\text { EU } \\
\text { Welfare }\end{array}$} & \multicolumn{2}{|c|}{$\begin{array}{c}\text { India } \\
\text { Japan, US } \\
\text { Welfare }\end{array}$} & \multicolumn{2}{|c|}{$\begin{array}{c}\text { Indonesia } \\
\text { ASEAN, Japan, US, } \\
\text { Welfare }\end{array}$} & \multicolumn{2}{|c|}{$\begin{array}{c}\text { China } \\
\text { Japan, Indonesia } \\
\text { Welfare }\end{array}$} & \multicolumn{2}{|c|}{$\begin{array}{c}\text { South Africa } \\
\text { EU } \\
\text { Welfare }\end{array}$} & \multicolumn{2}{|c|}{$\begin{array}{c}\text { Scenario } 3 \\
\text { Welfare }\end{array}$} \\
\hline & U.S.\$ & $\%$ of GDP & U.S.\$ & $\%$ of GDP & U.S.\$ & $\%$ of GDP & U.S.\$ & & U.S.\$ & $\%$ of GDP & U.S.\$ & $\%$ of GDP & U.S.\$ & $\%$ of GDP \\
\hline Japan & 0.1 & 0.0 & 0.7 & 0.0 & 7.2 & 0.1 & 3.8 & 0.1 & 45.2 & 0.6 & -0.1 & 0.0 & 57.3 & 0.8 \\
\hline United States & 20.5 & 0.1 & 2.3 & 0.0 & 16.1 & 0.1 & 8.0 & 0.0 & 0.9 & 0.0 & 0.4 & 0.0 & 48.4 & 0.3 \\
\hline Canada & 0.3 & 0.0 & 0.0 & 0.0 & 0.3 & 0.0 & 0.0 & 0.0 & 0.1 & 0.0 & 0.0 & 0.0 & 0.7 & 0.1 \\
\hline Australia & 0.0 & 0.0 & 0.0 & 0.0 & 0.0 & 0.0 & 0.3 & 0.0 & 0.3 & 0.1 & 0.0 & 0.0 & 0.6 & 0.1 \\
\hline New Zealand & 0.0 & 0.0 & 0.0 & 0.0 & 0.0 & 0.0 & 0.0 & 0.0 & 0.0 & 0.1 & 0.0 & 0.0 & 0.1 & 0.1 \\
\hline EU and EFTA & 33.5 & 0.2 & 39.0 & 0.3 & 0.7 & 0.0 & 0.2 & 0.0 & -0.2 & 0.0 & 12.0 & 0.1 & 85.5 & 0.6 \\
\hline China & 0.5 & 0.0 & 0.6 & 0.0 & 0.0 & 0.0 & 2.6 & 0.1 & 0.8 & 0.0 & 0.0 & 0.0 & 2.0 & 0.1 \\
\hline Hong Kong & 0.1 & 0.1 & 0.1 & 0.0 & 0.0 & 0.0 & 0.2 & 0.1 & -0.3 & -0.1 & 0.0 & 0.0 & 0.1 & 0.1 \\
\hline Indonesia & 0.0 & 0.0 & 0.0 & 0.0 & 0.0 & 0.0 & 11.8 & 4.6 & 2.9 & 1.1 & 0.0 & 0.0 & 11.7 & 4.5 \\
\hline Korea & -0.1 & 0.0 & 0.0 & 0.0 & 0.0 & 0.0 & -0.5 & -0.1 & -0.8 & -0.1 & 0.0 & 0.0 & -1.2 & -0.2 \\
\hline Malaysia & 0.0 & 0.0 & 0.0 & 0.0 & 0.0 & 0.0 & 3.7 & 2.4 & -0.3 & -0.2 & 0.0 & 0.0 & 3.3 & 2.2 \\
\hline Philippines & 0.0 & 0.0 & 0.0 & 0.0 & 0.0 & 0.0 & 1.8 & 1.4 & 0.0 & 0.0 & 0.0 & 0.0 & 1.8 & 1.4 \\
\hline Singapore & 0.0 & 0.0 & 0.1 & 0.1 & 0.0 & 0.0 & 2.6 & 1.8 & -0.1 & -0.1 & 0.0 & 0.0 & 2.7 & 1.9 \\
\hline Taiwan & 0.0 & 0.0 & 0.1 & 0.0 & 0.0 & 0.0 & -0.3 & -0.1 & -0.8 & -0.2 & 0.0 & 0.0 & -0.9 & -0.2 \\
\hline Thailand & 0.1 & 0.0 & 0.1 & 0.0 & 0.0 & 0.0 & 3.1 & 1.5 & -0.2 & -0.1 & 0.0 & 0.0 & 3.0 & 1.5 \\
\hline Vietnam & 0.0 & 0.0 & 0.0 & 0.1 & 0.0 & 0.0 & 0.6 & 1.0 & -0.1 & -0.1 & 0.0 & 0.0 & 0.5 & 0.9 \\
\hline India & 0.1 & 0.0 & 0.0 & 0.0 & 8.1 & 1.0 & -0.1 & 0.0 & -0.2 & 0.0 & 0.0 & 0.0 & 8.0 & 0.9 \\
\hline Rest of Asia & 0.1 & 0.0 & 0.1 & 0.0 & 0.0 & 0.0 & 0.2 & 0.0 & -0.1 & 0.0 & 0.0 & 0.0 & 0.3 & 0.1 \\
\hline Russia & 0.2 & 0.0 & 11.6 & 2.1 & 0.0 & 0.0 & 0.0 & 0.0 & 0.0 & 0.0 & 0.0 & 0.0 & 11.8 & 2.2 \\
\hline Turkey & 0.1 & 0.0 & 0.3 & 0.1 & 0.0 & 0.0 & 0.0 & 0.0 & 0.0 & 0.0 & 0.0 & 0.0 & 0.4 & 0.2 \\
\hline Rest of Middle East & 0.1 & 0.0 & 0.2 & 0.0 & 0.0 & 0.0 & 1.6 & 0.1 & 0.5 & 0.1 & 0.0 & 0.0 & 2.3 & 0.2 \\
\hline Mexico & 0.3 & 0.0 & 0.0 & 0.0 & 0.1 & 0.0 & -0.1 & 0.0 & 0.1 & 0.0 & 0.0 & 0.0 & 0.5 & 0.0 \\
\hline Argentina & -1.2 & -0.3 & 0.0 & 0.0 & 0.0 & 0.0 & 0.0 & 0.0 & 0.0 & 0.0 & 0.0 & 0.0 & -1.2 & -0.3 \\
\hline Brazil & 6.4 & 0.7 & 0.0 & 0.0 & 0.0 & 0.0 & 0.0 & 0.0 & 0.0 & 0.0 & -0.1 & 0.0 & 6.4 & 0.7 \\
\hline Chile & 0.1 & 0.1 & 0.0 & 0.0 & 0.0 & 0.0 & 0.0 & 0.0 & 0.1 & 0.1 & 0.0 & 0.0 & 0.2 & 0.2 \\
\hline Colombia & 0.0 & 0.0 & 0.0 & 0.0 & 0.0 & 0.0 & 0.0 & 0.0 & 0.0 & 0.0 & 0.0 & 0.0 & 0.1 & 0.1 \\
\hline Peru & 0.0 & 0.0 & 0.0 & 0.0 & 0.0 & 0.0 & 0.0 & 0.0 & 0.0 & 0.0 & 0.0 & 0.0 & 0.0 & 0.0 \\
\hline Uruguay & 0.0 & -0.1 & 0.0 & 0.0 & 0.0 & 0.0 & 0.0 & 0.0 & 0.0 & 0.0 & 0.0 & 0.0 & 0.0 & -0.1 \\
\hline Rest of Central and Latin America & 0.2 & 0.0 & 0.2 & 0.0 & 0.0 & 0.0 & 0.1 & 0.0 & 0.1 & 0.0 & 0.0 & 0.0 & 0.6 & 0.1 \\
\hline South Africa & 0.1 & 0.0 & -0.1 & 0.0 & 0.0 & 0.0 & 0.1 & 0.0 & 0.1 & 0.1 & 2.6 & 1.3 & 2.7 & 1.4 \\
\hline Africa & 0.3 & 0.0 & 0.0 & 0.0 & 0.0 & 0.0 & 0.2 & 0.0 & 0.1 & 0.0 & 0.1 & 0.0 & 0.7 & 0.1 \\
\hline Total & 61.9 & & 55.3 & & 32.5 & & 39.6 & & 48.1 & & 15.0 & & 248.2 & \\
\hline
\end{tabular}


CHAPTER 5: STORM IN A SPAGHETTI BOWL: FTA’S AND THE BRIICS - 21

Annex Table 5A.5. Scenario 4 - Global Welfare Effects of BRIICS Free Trade Agreements

(billions of U.S. dollars and percentage)

\begin{tabular}{|c|c|c|c|c|c|c|c|c|c|c|c|c|c|c|}
\hline \multirow{3}{*}{$\begin{array}{lc} & \text { Home } \\
& \text { Partner } \\
& \\
\text { Japan } & \end{array}$} & \multicolumn{2}{|c|}{$\begin{array}{c}\text { Brazil } \\
\text { US, EU } \\
\text { Welfare }\end{array}$} & \multicolumn{2}{|c|}{$\begin{array}{l}\text { Russia } \\
\text { EU } \\
\text { Welfare }\end{array}$} & \multicolumn{2}{|c|}{$\begin{array}{c}\text { India } \\
\text { Japan, US, ASEAN } \\
\text { Welfare }\end{array}$} & \multicolumn{2}{|c|}{\begin{tabular}{|c|} 
Indonesia \\
ASEAN, Japan, US, \\
Welfare
\end{tabular}} & \multicolumn{2}{|c|}{$\begin{array}{c}\text { China } \\
\text { Japan, ASEAN } \\
\text { Welfare }\end{array}$} & \multicolumn{2}{|c|}{$\begin{array}{c}\text { South Africa } \\
\text { EU } \\
\text { Welfare }\end{array}$} & \multicolumn{2}{|c|}{$\begin{array}{c}\text { Scenario } 4 \\
\text { Welfare }\end{array}$} \\
\hline & U.S.\$ & $\%$ of GDP & U.S.\$ & $\%$ of GDP & U.S.\$ & $\%$ of GDP & U.S.\$ & $\%$ of GDP & U.S.\$ & $\%$ of GDP & U.S.\$ & $\%$ of GDP & U.S.\$ & $\%$ of GDP \\
\hline & 0.1 & 0.0 & 0.7 & 0.0 & 7.5 & 0.1 & 2.8 & 0.0 & 44.0 & 0.6 & -0.1 & 0.0 & 56.4 & 0.8 \\
\hline United States & 20.5 & 0.1 & 2.3 & 0.0 & 16.1 & 0.1 & 6.6 & 0.0 & -0.5 & 0.0 & 0.4 & 0.0 & 47.0 & 0.3 \\
\hline Canada & 0.3 & 0.0 & 0.0 & 0.0 & 0.2 & 0.0 & -0.5 & 0.0 & -0.3 & 0.0 & 0.0 & 0.0 & 0.3 & 0.0 \\
\hline Australia & 0.0 & 0.0 & 0.0 & 0.0 & 0.0 & 0.0 & 0.3 & 0.1 & 0.4 & 0.1 & 0.0 & 0.0 & 0.6 & 0.1 \\
\hline New Zealand & 0.0 & 0.0 & 0.0 & 0.0 & 0.0 & 0.0 & 0.0 & 0.0 & 0.0 & 0.1 & 0.0 & 0.0 & 0.1 & 0.1 \\
\hline EU and EFTA & 33.5 & 0.2 & 39.0 & 0.3 & -0.3 & 0.0 & -4.5 & 0.0 & -3.8 & 0.0 & 12.0 & 0.1 & 80.8 & 0.5 \\
\hline China & 0.5 & 0.0 & 0.6 & 0.0 & 0.5 & 0.0 & 15.2 & 0.7 & 12.8 & 0.6 & 0.0 & 0.0 & 14.5 & 0.7 \\
\hline Hong Kong & 0.1 & 0.1 & 0.1 & 0.0 & 0.1 & 0.0 & 0.3 & 0.1 & -0.2 & -0.1 & 0.0 & 0.0 & 0.2 & 0.1 \\
\hline Indonesia & 0.0 & 0.0 & 0.0 & 0.0 & 1.6 & 0.6 & 13.5 & 5.2 & 3.0 & 1.2 & 0.0 & 0.0 & 13.3 & 5.2 \\
\hline Korea & -0.1 & 0.0 & 0.0 & 0.0 & 0.0 & 0.0 & -1.1 & -0.2 & -1.4 & -0.2 & 0.0 & 0.0 & -1.7 & -0.2 \\
\hline Malaysia & 0.0 & 0.0 & 0.0 & 0.0 & 1.7 & 1.1 & 11.4 & 7.5 & 5.6 & 3.7 & 0.0 & 0.0 & 11.0 & 7.2 \\
\hline Philippines & 0.0 & 0.0 & 0.0 & 0.0 & 0.4 & 0.3 & 3.2 & 2.6 & 1.1 & 0.9 & 0.0 & 0.0 & 3.3 & 2.6 \\
\hline Singapore & 0.0 & 0.0 & 0.1 & 0.1 & 0.6 & 0.4 & 5.1 & 3.6 & 1.9 & 1.3 & 0.0 & 0.0 & 5.2 & 3.7 \\
\hline Taiwan & 0.0 & 0.0 & 0.1 & 0.0 & 0.0 & 0.0 & -0.5 & -0.1 & -1.0 & -0.2 & 0.0 & 0.0 & -1.1 & -0.2 \\
\hline Thailand & 0.1 & 0.0 & 0.1 & 0.0 & 1.1 & 0.5 & 8.5 & 4.2 & 4.1 & 2.0 & 0.0 & 0.0 & 8.4 & 4.1 \\
\hline Vietnam & 0.0 & 0.0 & 0.0 & 0.1 & 0.2 & 0.3 & 0.9 & 1.5 & 0.1 & 0.2 & 0.0 & 0.0 & 0.9 & 1.5 \\
\hline India & 0.1 & 0.0 & 0.0 & 0.0 & 15.4 & 1.8 & 7.0 & 0.8 & -0.3 & 0.0 & 0.0 & 0.0 & 15.2 & 1.8 \\
\hline Rest of Asia & 0.1 & 0.0 & 0.1 & 0.0 & 0.3 & 0.1 & 0.6 & 0.1 & 0.0 & 0.0 & 0.0 & 0.0 & 0.7 & 0.2 \\
\hline Russia & 0.2 & 0.0 & 11.6 & 2.1 & 0.1 & 0.0 & -0.2 & 0.0 & -0.3 & -0.1 & 0.0 & 0.0 & 11.6 & 2.1 \\
\hline Turkey & 0.1 & 0.0 & 0.3 & 0.1 & 0.1 & 0.0 & 0.1 & 0.0 & 0.0 & 0.0 & 0.0 & 0.0 & 0.5 & 0.2 \\
\hline Rest of Middle East & 0.1 & 0.0 & 0.2 & 0.0 & 0.0 & 0.0 & 2.2 & 0.2 & 1.1 & 0.1 & 0.0 & 0.0 & 2.8 & 0.3 \\
\hline Mexico & 0.3 & 0.0 & 0.0 & 0.0 & 0.0 & 0.0 & -0.3 & 0.0 & -0.1 & 0.0 & 0.0 & 0.0 & 0.3 & 0.0 \\
\hline Argentina & -1.2 & -0.3 & 0.0 & 0.0 & -0.1 & 0.0 & -0.1 & 0.0 & -0.1 & 0.0 & 0.0 & 0.0 & -1.3 & -0.3 \\
\hline Brazil & 6.4 & 0.7 & 0.0 & 0.0 & 0.0 & 0.0 & -0.2 & 0.0 & -0.1 & 0.0 & -0.1 & 0.0 & 6.2 & 0.7 \\
\hline Chile & 0.1 & 0.1 & 0.0 & 0.0 & 0.0 & 0.0 & 0.0 & 0.0 & 0.0 & 0.0 & 0.0 & 0.0 & 0.2 & 0.2 \\
\hline Colombia & 0.0 & 0.0 & 0.0 & 0.0 & 0.0 & 0.0 & 0.0 & 0.0 & 0.0 & 0.0 & 0.0 & 0.0 & 0.1 & 0.1 \\
\hline Peru & 0.0 & 0.0 & 0.0 & 0.0 & -0.2 & -0.1 & -0.2 & -0.1 & 0.0 & 0.0 & 0.0 & 0.0 & -0.2 & -0.1 \\
\hline Uruguay & 0.0 & -0.1 & 0.0 & 0.0 & 0.0 & 0.0 & 0.0 & 0.0 & 0.0 & 0.0 & 0.0 & 0.0 & 0.0 & -0.1 \\
\hline Rest of Central and Latin America & 0.2 & 0.0 & 0.2 & 0.0 & 0.0 & 0.0 & 0.0 & 0.0 & 0.0 & 0.0 & 0.0 & 0.0 & 0.6 & 0.1 \\
\hline South Africa & 0.1 & 0.0 & -0.1 & 0.0 & -0.1 & -0.1 & 0.0 & 0.0 & 0.1 & 0.0 & 2.6 & 1.3 & 2.6 & 1.3 \\
\hline Africa & 0.3 & 0.0 & 0.0 & 0.0 & 0.2 & 0.0 & 0.3 & 0.0 & -0.1 & 0.0 & 0.1 & 0.0 & 0.7 & 0.1 \\
\hline Total & 61.9 & & 55.3 & & 45.2 & & 70.4 & & 66.2 & & 15.0 & & 279.0 & \\
\hline
\end{tabular}

Annex Table 5A.6. Scenario 5 - Global Welfare Effects of BRIICS Free Trade Agreements

(billions of U.S. dollars and percentage)

\begin{tabular}{|c|c|c|c|c|c|c|c|c|c|c|c|c|c|c|}
\hline \multirow{3}{*}{$\begin{array}{lc} & \text { Home } \\
& \text { Partner } \\
& \\
\text { Japan } & \end{array}$} & \multicolumn{2}{|c|}{$\begin{array}{l}\text { Brazil } \\
\text { US, EU } \\
\text { Welfare }\end{array}$} & \multicolumn{2}{|c|}{$\begin{array}{l}\text { Russia } \\
\text { EU } \\
\text { Welfare }\end{array}$} & \multicolumn{2}{|c|}{\begin{tabular}{|c|} 
India \\
Japan, US, ASEAN, \\
Welfare
\end{tabular}} & \multicolumn{2}{|c|}{\begin{tabular}{|c|} 
Indonesia \\
ASEAN, Japan, US, \\
Welfare
\end{tabular}} & \multicolumn{2}{|c|}{\begin{tabular}{|c|} 
China \\
Japan, ASEAN, India \\
Welfare
\end{tabular}} & \multicolumn{2}{|c|}{$\begin{array}{c}\text { South Africa } \\
\text { EU } \\
\text { Welfare }\end{array}$} & \multicolumn{2}{|c|}{$\begin{array}{c}\text { Scenario } 5 \\
\text { Welfare }\end{array}$} \\
\hline & U.S.\$ & $\%$ of GDP & U.S.\$ & $\%$ of GDP & U.S.\$ & & U.S. $\$$ & & U.S.\$ & $\%$ of GDP & U.S.\$ & $\%$ of GDP & U.S.\$ & $\%$ of GDP \\
\hline & 0.1 & 0.0 & 0.7 & 0.0 & 7.6 & 0.1 & 2.8 & 0.0 & 44.1 & 0.6 & -0.1 & 0.0 & 56.5 & 0.8 \\
\hline United States & 20.5 & 0.1 & 2.3 & 0.0 & 16.2 & 0.1 & 6.6 & 0.0 & -0.4 & 0.0 & 0.4 & 0.0 & 47.1 & 0.3 \\
\hline Canada & 0.3 & 0.0 & 0.0 & 0.0 & 0.2 & 0.0 & -0.5 & 0.0 & -0.2 & 0.0 & 0.0 & 0.0 & 0.3 & 0.0 \\
\hline Australia & 0.0 & 0.0 & 0.0 & 0.0 & 0.0 & 0.0 & 0.3 & 0.1 & 0.4 & 0.1 & 0.0 & 0.0 & 0.6 & 0.1 \\
\hline New Zealand & 0.0 & 0.0 & 0.0 & 0.0 & 0.0 & 0.0 & 0.0 & 0.0 & 0.0 & 0.1 & 0.0 & 0.0 & 0.1 & 0.1 \\
\hline EU and EFTA & 33.5 & 0.2 & 39.0 & 0.3 & -0.2 & 0.0 & -4.5 & 0.0 & -3.8 & 0.0 & 12.0 & 0.1 & 80.9 & 0.5 \\
\hline China & 0.5 & 0.0 & 0.6 & 0.0 & 4.8 & 0.2 & 15.2 & 0.7 & 17.1 & 0.8 & 0.0 & 0.0 & 18.8 & 0.9 \\
\hline Hong Kong & 0.1 & 0.1 & 0.1 & 0.0 & 0.1 & 0.1 & 0.3 & 0.1 & -0.2 & -0.1 & 0.0 & 0.0 & 0.3 & 0.1 \\
\hline Indonesia & 0.0 & 0.0 & 0.0 & 0.0 & 1.6 & 0.6 & 13.5 & 5.2 & 3.0 & 1.2 & 0.0 & 0.0 & 13.3 & 5.2 \\
\hline Korea & -0.1 & 0.0 & 0.0 & 0.0 & 0.1 & 0.0 & -1.1 & -0.2 & -1.3 & -0.2 & 0.0 & 0.0 & -1.7 & -0.2 \\
\hline Malaysia & 0.0 & 0.0 & 0.0 & 0.0 & 1.7 & 1.1 & 11.4 & 7.5 & 5.6 & 3.7 & 0.0 & 0.0 & 11.0 & 7.2 \\
\hline Philippines & 0.0 & 0.0 & 0.0 & 0.0 & 0.4 & 0.3 & 3.2 & 2.6 & 1.1 & 0.9 & 0.0 & 0.0 & 3.3 & 2.6 \\
\hline Singapore & 0.0 & 0.0 & 0.1 & 0.1 & 0.6 & 0.4 & 5.1 & 3.6 & 1.9 & 1.3 & 0.0 & 0.0 & 5.2 & 3.7 \\
\hline Taiwan & 0.0 & 0.0 & 0.1 & 0.0 & 0.0 & 0.0 & -0.5 & -0.1 & -1.0 & -0.2 & 0.0 & 0.0 & -1.1 & -0.2 \\
\hline Thailand & 0.1 & 0.0 & 0.1 & 0.0 & 1.1 & 0.5 & 8.5 & 4.2 & 4.1 & 2.0 & 0.0 & 0.0 & 8.4 & 4.1 \\
\hline Vietnam & 0.0 & 0.0 & 0.0 & 0.1 & 0.2 & 0.3 & 0.9 & 1.5 & 0.1 & 0.2 & 0.0 & 0.0 & 0.9 & 1.5 \\
\hline India & 0.1 & 0.0 & 0.0 & 0.0 & 18.2 & 2.1 & 7.0 & 0.8 & 2.5 & 0.3 & 0.0 & 0.0 & 18.0 & 2.1 \\
\hline Rest of Asia & 0.1 & 0.0 & 0.1 & 0.0 & 0.3 & 0.1 & 0.6 & 0.1 & 0.0 & 0.0 & 0.0 & 0.0 & 0.7 & 0.2 \\
\hline Russia & 0.2 & 0.0 & 11.6 & 2.1 & 0.1 & 0.0 & -0.2 & 0.0 & -0.3 & -0.1 & 0.0 & 0.0 & 11.6 & 2.1 \\
\hline Turkey & 0.1 & 0.0 & 0.3 & 0.1 & 0.1 & 0.0 & 0.1 & 0.0 & 0.0 & 0.0 & 0.0 & 0.0 & 0.5 & 0.2 \\
\hline Rest of Middle East & 0.1 & 0.0 & 0.2 & 0.0 & 0.0 & 0.0 & 2.2 & 0.2 & 1.0 & 0.1 & 0.0 & 0.0 & 2.8 & 0.2 \\
\hline Mexico & 0.3 & 0.0 & 0.0 & 0.0 & 0.0 & 0.0 & -0.3 & 0.0 & -0.1 & 0.0 & 0.0 & 0.0 & 0.2 & 0.0 \\
\hline Argentina & -1.2 & -0.3 & 0.0 & 0.0 & -0.1 & 0.0 & -0.1 & 0.0 & -0.1 & 0.0 & 0.0 & 0.0 & -1.3 & -0.3 \\
\hline Brazil & 6.4 & 0.7 & 0.0 & 0.0 & 0.0 & 0.0 & -0.2 & 0.0 & -0.1 & 0.0 & -0.1 & 0.0 & 6.2 & 0.7 \\
\hline Chile & 0.1 & 0.1 & 0.0 & 0.0 & 0.0 & 0.0 & 0.0 & 0.0 & 0.0 & 0.0 & 0.0 & 0.0 & 0.2 & 0.2 \\
\hline Colombia & 0.0 & 0.0 & 0.0 & 0.0 & 0.0 & 0.0 & 0.0 & 0.0 & 0.0 & 0.0 & 0.0 & 0.0 & 0.1 & 0.1 \\
\hline Peru & 0.0 & 0.0 & 0.0 & 0.0 & -0.2 & -0.1 & -0.2 & -0.1 & 0.0 & 0.0 & 0.0 & 0.0 & -0.2 & -0.1 \\
\hline Uruguay & 0.0 & -0.1 & 0.0 & 0.0 & 0.0 & 0.0 & 0.0 & 0.0 & 0.0 & 0.0 & 0.0 & 0.0 & 0.0 & -0.1 \\
\hline Rest of Central and Latin America & 0.2 & 0.0 & 0.2 & 0.0 & 0.0 & 0.0 & 0.0 & 0.0 & 0.0 & 0.0 & 0.0 & 0.0 & 0.6 & 0.1 \\
\hline South Africa & 0.1 & 0.0 & -0.1 & 0.0 & -0.1 & -0.1 & 0.0 & 0.0 & 0.0 & 0.0 & 2.6 & 1.3 & 2.6 & 1.3 \\
\hline Africa & 0.3 & 0.0 & 0.0 & 0.0 & 0.2 & 0.0 & 0.3 & 0.0 & -0.1 & 0.0 & 0.1 & 0.0 & 0.7 & 0.1 \\
\hline Total & 61.9 & & 55.3 & & 52.6 & & 70.4 & & 73.5 & & 15.0 & & 286.4 & \\
\hline
\end{tabular}


Annex Table 5A.7. Scenario 1 - BRIICS Free Trade Agreements: Change in Exports for BRIICS countries, Japan, EU and the United States

\begin{tabular}{|c|c|c|c|c|c|c|c|c|c|c|c|c|c|c|c|c|c|c|}
\hline \multirow[b]{3}{*}{ Rice } & \multicolumn{2}{|c|}{ Brazil } & \multicolumn{2}{|c|}{ Russia } & \multicolumn{2}{|c|}{ India } & \multicolumn{2}{|c|}{ Indonesia } & \multicolumn{2}{|c|}{ China } & \multicolumn{2}{|c|}{ South Africa } & \multicolumn{2}{|c|}{ Japan } & \multicolumn{2}{|c|}{ EU/EFTA } & \multicolumn{2}{|c|}{ United States } \\
\hline & Value & Percent & Value & Percent & Value & Percent & Value & Percent & Value & Percent & Value & Percent & Value & Percent & Value & Percent & Value & Percent \\
\hline & 0.0 & 0.9 & 0.1 & 0.6 & 3.0 & 1.0 & 0.0 & 3.1 & 5.4 & 3.7 & 0.0 & 0.0 & -29.7 & -1.8 & 0.0 & 0.0 & 1.9 & 0.3 \\
\hline Wheat & 0.0 & 1.0 & -1.9 & -0.6 & 7.8 & 1.0 & 0.0 & -0.1 & 0.5 & 0.6 & 0.5 & 0.6 & 0.0 & -1.5 & -6.2 & -0.3 & -9.3 & -0.1 \\
\hline Other grains & 8.3 & 0.6 & -11.1 & -5.1 & 0.6 & 1.3 & 2.6 & 24.6 & 67.0 & 4.7 & -3.3 & -1.0 & 0.0 & -0.6 & 1.9 & 0.1 & -63.8 & -0.6 \\
\hline Vegetables and fruits & 18.0 & 2.3 & 2.6 & 1.5 & 20.1 & 1.5 & 17.7 & 5.8 & 482.9 & 12.2 & 329.7 & 16.0 & 0.7 & 1.1 & 103.9 & 4.1 & 19.5 & 0.2 \\
\hline Oil seeds & 59.5 & 1.2 & 3.2 & 2.0 & 4.5 & 1.0 & 0.8 & 3.0 & 13.1 & 1.4 & 0.3 & 0.5 & 0.2 & 2.8 & -0.6 & -0.2 & -12.0 & -0.1 \\
\hline Sugar & 0.0 & 1.4 & 0.0 & 1.2 & 0.1 & 1.1 & 0.0 & -0.3 & 0.1 & 0.7 & 0.0 & 4.2 & 0.0 & -1.0 & 0.0 & -0.3 & 0.1 & 1.3 \\
\hline Plant-based fibers & 3.6 & 1.1 & 0.5 & 0.4 & 1.1 & 1.2 & 0.0 & 0.5 & -0.7 & -0.4 & 0.5 & 1.1 & 0.1 & 3.3 & 3.8 & 0.5 & -6.1 & -0.1 \\
\hline Other crops & 193.8 & 4.1 & 0.4 & 0.6 & 10.3 & 0.4 & 53.4 & 1.4 & 79.8 & 3.0 & 16.6 & 3.8 & -0.8 & -0.3 & 73.2 & 1.6 & -17.5 & -0.3 \\
\hline Livestock & 7.2 & 1.9 & 14.3 & 2.9 & 3.1 & 1.1 & 4.4 & 2.4 & 59.9 & 1.9 & 1.0 & 0.3 & 24.8 & 9.5 & 7.3 & 0.2 & -10.5 & -0.2 \\
\hline Other natural resources & 3.3 & 2.2 & 124.4 & 4.2 & 1.4 & 1.2 & 32.9 & 3.4 & 53.6 & 4.8 & 31.8 & 12.2 & -1.4 & -0.6 & 15.0 & 0.9 & 14.1 & 0.5 \\
\hline Mining & 105.8 & 1.4 & 1917.0 & 2.7 & 17.1 & 0.7 & -145.7 & -0.7 & 1.2 & 0.0 & 147.7 & 1.9 & 8.7 & 3.4 & -148.8 & -0.9 & -19.0 & -0.2 \\
\hline Food, Beverages \& Tobacco & 325.1 & 1.9 & -13.7 & -0.3 & 172.0 & 2.5 & 564.1 & 7.2 & 3772.7 & 22.8 & 190.6 & 5.2 & 158.0 & 3.9 & 1773.3 & 2.5 & 61.2 & 0.1 \\
\hline Textiles & 117.3 & 7.0 & 86.2 & 9.2 & 61.9 & 0.5 & 294.2 & 3.7 & 2381.7 & 5.5 & 16.1 & 1.7 & 5039.3 & 30.5 & 51.8 & 0.1 & -110.6 & -0.5 \\
\hline Wearing Apparel & 45.0 & 9.7 & 113.4 & 13.5 & 82.1 & 0.8 & 219.9 & 2.6 & 8850.3 & 13.1 & 22.2 & 4.1 & 72.1 & 8.2 & 244.5 & 1.4 & -87.1 & -1.0 \\
\hline Leather Products \& & 764.8 & 16.4 & 4.3 & 1.5 & 13.3 & 0.4 & 23.0 & 0.4 & 2146.7 & 3.7 & -1.2 & -0.3 & 15.6 & 3.0 & -16.5 & -0.1 & -57.1 & -1.7 \\
\hline Wood \& Wood Products & 200.1 & 2.3 & 279.2 & 4.3 & 6.2 & 0.5 & 730.5 & 4.4 & 363.8 & 1.3 & 31.1 & 0.9 & 253.8 & 4.5 & 879.9 & 1.6 & 40.9 & 0.1 \\
\hline Chemicals & 315.5 & 3.1 & 2408.6 & 8.8 & 16.4 & 0.1 & 97.9 & 0.9 & 13.2 & 0.0 & 79.6 & 1.1 & 3448.7 & 4.5 & 1558.8 & 0.7 & 1120.3 & 0.6 \\
\hline Non-metallic Min. Products & 136.3 & 5.8 & 55.7 & 3.6 & 8.0 & 0.4 & 91.0 & 4.5 & 14.4 & 0.1 & 7.6 & 0.9 & 495.5 & 3.8 & 464.4 & 1.4 & 142.1 & 0.6 \\
\hline Metal Products & 281.0 & 2.5 & 3368.0 & 8.6 & 7.1 & 0.1 & 177.8 & 3.0 & -93.2 & -0.3 & 582.4 & 2.8 & 1794.4 & 3.6 & 338.5 & 0.4 & 106.3 & 0.2 \\
\hline Transportation Equipment & 447.6 & 2.8 & 228.6 & 3.4 & 0.1 & 0.0 & 123.8 & 9.8 & -111.7 & -0.7 & 402.1 & 8.1 & 1577.5 & 0.9 & 2335.3 & 1.2 & 38.0 & 0.0 \\
\hline Machinery \& Equipment & 251.7 & 1.8 & 176.4 & 2.3 & 25.2 & 0.3 & 761.7 & 3.5 & -103.6 & 0.0 & 85.7 & 1.3 & 12068.4 & 3.2 & -383.6 & -0.1 & 2682.2 & 0.5 \\
\hline Other Manufactures & 46.4 & 3.8 & 120.5 & 5.8 & 134.4 & 1.0 & 43.4 & 1.9 & 1183.8 & 1.6 & 40.0 & 1.4 & 174.7 & 1.1 & 81.4 & 0.1 & 38.2 & 0.1 \\
\hline Construction & 0.2 & 1.2 & 7.6 & 0.8 & 0.0 & 0.1 & -0.1 & -0.4 & -0.9 & -0.1 & 8.4 & 1.3 & -0.3 & -1.2 & -53.4 & -0.9 & -4.0 & -0.2 \\
\hline Elec., Gas \& Water & 0.7 & 1.3 & 22.1 & 10.8 & 0.2 & 0.7 & 7.5 & 2.5 & 13.8 & 1.0 & 0.3 & 3.6 & 82.8 & 1.1 & 146.1 & 1.0 & 8.0 & 0.2 \\
\hline Trade \& Transp & 175.0 & 4.2 & 1094.0 & & 224.8 & 2.6 & 61.5 & 2.0 & 620.0 & 2.4 & 528.1 & 11.3 & 395.5 & 1.2 & 3067.8 & 1.4 & 253.4 & 0.2 \\
\hline Other Private Services & 653.9 & 6.6 & 786.9 & 15.5 & 242.7 & 1.9 & 48.0 & 1.3 & 116.6 & 1.4 & 141.6 & 9.9 & 4.8 & 0.0 & 3917.2 & 1.4 & 1070.8 & 0.5 \\
\hline Government Services & 199.0 & 15.9 & 262.0 & 15.2 & 24.7 & 1.8 & 4.7 & 1.4 & 86.0 & 2.0 & 57.0 & 10.6 & -10.9 & -0.4 & 168.5 & 0.4 & 357.2 & 0.5 \\
\hline Total & 4360 & & 11049 & & 1088 & & 3215 & & 20016 & & 2717 & & 25573 & & 14623 & & 5557 & \\
\hline
\end{tabular}

Annex Table 5A.8. Scenario 5 - BRIICS Free Trade Agreements: Change in Exports for BRIICS countries, Japan, EU and the United States

\begin{tabular}{|c|c|c|c|c|c|c|c|c|c|c|c|c|c|c|c|c|c|c|}
\hline \multirow[b]{3}{*}{ Rice } & \multirow{2}{*}{\multicolumn{2}{|c|}{ Brazil }} & \multicolumn{2}{|c|}{ Russia } & \multicolumn{2}{|c|}{ India } & \multicolumn{2}{|c|}{ Indonesia } & \multicolumn{2}{|c|}{ China } & \multicolumn{2}{|c|}{ South Africa } & \multicolumn{2}{|c|}{ Japan } & \multicolumn{2}{|c|}{ EU/EFTA } & \multicolumn{2}{|c|}{ United States } \\
\hline & & Percent & Value & Percent & Value & Percent & Value & Percent & Value & Percent & Value & Percent & Value & Percent & Value & Percent & Value & Percent \\
\hline & 0.1 & 2.9 & 0.1 & 0.5 & 9.6 & 3.2 & 0.1 & 9.5 & 12.2 & 8.4 & 0.0 & 0.1 & -35.9 & -2.2 & 0.1 & 0.6 & 1.3 & 0.2 \\
\hline Wheat & 0.0 & 2.4 & -2.0 & -0.6 & 38.8 & 5.1 & -0.7 & -3.4 & 2.1 & 2.1 & 0.6 & 0.7 & 0.0 & -1.6 & -11.8 & -0.5 & -19.6 & -0.3 \\
\hline Other grains & 2.5 & 0.2 & -11.2 & -5.2 & 2.3 & 4.8 & 2.3 & 22.0 & 102.1 & 7.1 & -3.1 & -1.0 & 0.0 & -0.3 & -3.3 & -0.2 & -73.4 & -0.7 \\
\hline Vegetables and fruits & 92.3 & 11.7 & 2.9 & 1.7 & 56.5 & 4.2 & 33.4 & 11.0 & 618.8 & 15.6 & 336.9 & 16.4 & 1.1 & 1.8 & 111.2 & 4.4 & 144.9 & 1.6 \\
\hline Oil seeds & 383.6 & 7.5 & 1.0 & 0.6 & 29.0 & 6.3 & 1.6 & 5.8 & 17.9 & 2.0 & -0.1 & -0.2 & 0.2 & 2.5 & -1.4 & -0.4 & -34.7 & -0.3 \\
\hline Sugar & 0.0 & 8.0 & 0.0 & 1.8 & 0.3 & 2.6 & 0.0 & -2.0 & 0.1 & 1.1 & 0.0 & 5.3 & 0.0 & 0.1 & 0.0 & -0.4 & 0.1 & 1.2 \\
\hline Plant-based fibers & 14.0 & 4.4 & 0.1 & 0.1 & 2.3 & 2.5 & 0.0 & -0.7 & 2.7 & 1.6 & 3.3 & 7.1 & 0.3 & 8.1 & 11.6 & 1.5 & 96.7 & 2.4 \\
\hline Other crops & 577.0 & 12.3 & 0.4 & 0.5 & 79.4 & 3.3 & -1.5 & 0.0 & 180.5 & 6.8 & 16.3 & 3.7 & -1.6 & -0.5 & 79.2 & 1.7 & 4.3 & 0.1 \\
\hline Livestock & 16.5 & 4.3 & 14.7 & 3.0 & 12.6 & 4.4 & 0.5 & 0.3 & 169.0 & 5.3 & 2.0 & 0.6 & 25.7 & 9.9 & 14.4 & 0.4 & 0.7 & 0.0 \\
\hline Other natural resources & 9.9 & 6.5 & 131.3 & 4.4 & 5.6 & 4.9 & 57.8 & 6.0 & 57.2 & 5.2 & 32.8 & 12.6 & -1.1 & -0.5 & 16.0 & 0.9 & 17.1 & 0.6 \\
\hline Mining & 257.1 & 3.3 & 1995.2 & 2.8 & 46.8 & 2.0 & -616.3 & -3.2 & 402.1 & 4.7 & 155.3 & 2.0 & 11.1 & 4.4 & -182.4 & -1.1 & -10.5 & -0.1 \\
\hline Food, Beverages \& Tobacco & 4733.7 & 28.0 & -17.9 & -0.3 & 677.0 & 10.0 & 1368.6 & 17.6 & 4195.9 & 25.4 & 193.1 & 5.2 & 158.6 & 3.9 & 1916.7 & 2.7 & 276.0 & 0.5 \\
\hline Textiles & 179.1 & 10.7 & 83.7 & 9.0 & 1324.4 & 9.8 & 1531.9 & 19.1 & 3266.0 & 7.5 & 13.5 & 1.4 & 4934.8 & 29.9 & -18.2 & -0.1 & -197.6 & -0.9 \\
\hline Wearing Apparel & 60.3 & 13.1 & 104.4 & 12.4 & 2405.4 & 23.5 & 3027.3 & 35.2 & 9088.5 & 13.5 & 16.8 & 3.1 & 66.5 & 7.5 & 112.9 & 0.6 & -138.2 & -1.5 \\
\hline Leather Products \& Footwear & 1052.2 & 22.6 & 3.4 & 1.2 & 259.3 & 8.5 & 1577.2 & 29.4 & 1673.6 & 2.9 & -2.5 & -0.7 & 14.9 & 2.9 & -174.8 & -0.9 & -65.0 & -1.9 \\
\hline Wood \& Wood Products & 371.8 & 4.4 & 274.8 & 4.2 & 47.5 & 3.8 & 884.9 & 5.4 & 570.0 & 2.0 & 41.8 & 1.2 & 274.3 & 4.9 & 1090.1 & 2.0 & 169.9 & 0.3 \\
\hline Chemicals & 460.5 & 4.6 & 2325.9 & 8.5 & 868.9 & 6.3 & 534.4 & 5.0 & 1932.1 & 3.9 & 69.0 & 1.0 & 3288.0 & 4.3 & 2634.7 & 1.1 & 1859.7 & 1.0 \\
\hline Non-metallic Min. Products & 186.1 & 8.0 & 54.7 & 3.5 & 91.4 & 5.0 & 131.4 & 6.5 & 372.2 & 2.4 & 8.5 & 1.0 & 502.8 & 3.9 & 609.8 & 1.8 & 224.1 & 0.9 \\
\hline Metal Products & 646.1 & 5.8 & 3371.5 & 8.6 & 342.3 & 5.1 & -147.3 & -2.5 & 757.9 & 2.3 & 479.9 & 2.3 & 1871.2 & 3.8 & 746.7 & 0.9 & 312.5 & 0.5 \\
\hline Transportation Equipment & 916.9 & 5.8 & 181.8 & 2.7 & 98.4 & 4.7 & 87.2 & 6.9 & 886.2 & 5.8 & 400.8 & 8.0 & 1496.7 & 0.9 & 3350.7 & 1.7 & 146.5 & 0.1 \\
\hline Machinery \& Equipment & 378.1 & 2.7 & 153.2 & 2.0 & 270.7 & 3.6 & 586.8 & 2.7 & 4176.8 & 1.9 & 82.7 & 1.3 & 11829.3 & 3.1 & 2155.4 & 0.5 & 3328.4 & 0.7 \\
\hline Other Manufactures & 57.0 & 4.7 & 121.6 & 5.8 & 780.8 & 5.8 & -47.5 & -2.1 & 1777.3 & 2.3 & 43.4 & 1.6 & 175.1 & 1.1 & -170.7 & -0.3 & 260.2 & 1.0 \\
\hline Construction & 0.4 & 2.5 & 7.2 & 0.8 & 0.5 & 2.0 & -1.0 & -4.0 & 3.5 & 0.6 & 7.7 & 1.2 & -0.3 & -1.1 & -85.3 & -1.4 & -4.5 & -0.2 \\
\hline Elec., Gas \& Water & 3.5 & 6.6 & 22.3 & 10.9 & 1.4 & 4.5 & 5.4 & 1.8 & 37.4 & 2.8 & 0.3 & 3.6 & 92.6 & 1.3 & 152.1 & 1.1 & 13.2 & 0.3 \\
\hline Trade \& Transport & 657.9 & 15.7 & 1099.9 & 14.7 & 1046.0 & 12.2 & 204.5 & 6.8 & 1169.7 & 4.6 & 537.1 & 11.5 & 419.9 & 1.3 & 4735.6 & 2.2 & 755.1 & 0.7 \\
\hline Other Priva & 2030.1 & 20.4 & 799.3 & 15.7 & 1544.4 & 12.4 & 142.2 & 3.8 & 276.8 & 3.4 & 145.2 & 10.1 & 61.7 & 0.2 & 7530.3 & 2.7 & 3174.8 & 1.6 \\
\hline Government Services & 259.8 & 20.7 & 265.1 & 15.4 & 229.4 & 16.8 & 25.0 & 7.7 & 149.8 & 3.5 & 58.2 & 10.8 & -9.1 & -0.3 & 318.4 & 0.7 & 772.7 & 1.0 \\
\hline Total & 13347 & & 10983 & & 10271 & & 9388 & & 31898 & & 2639 & & 25177 & & 24938 & & 11015 & \\
\hline
\end{tabular}


Annex Table 5A.9. Welfare Effects of BRIICS Free Trade Agreements

(billions of U.S. dollars and percentage)

\begin{tabular}{|c|c|c|c|c|c|c|c|c|c|c|}
\hline \multirow[b]{3}{*}{ Brazil } & \multicolumn{2}{|c|}{$\begin{array}{c}\text { Scenario } 1 \\
\text { Welfare }\end{array}$} & \multicolumn{2}{|c|}{$\begin{array}{c}\text { Scenario } 2 \\
\text { Welfare }\end{array}$} & \multicolumn{2}{|c|}{$\begin{array}{c}\text { Scenario } 3 \\
\text { Welfare }\end{array}$} & \multicolumn{2}{|c|}{$\begin{array}{c}\text { Scenario } 4 \\
\text { Welfare }\end{array}$} & \multicolumn{2}{|c|}{$\begin{array}{c}\text { Scenario } 5 \\
\text { Welfare }\end{array}$} \\
\hline & U.S.\$ & $\%$ of GDP & U.S.\$ & $\%$ of GDP & U.S.\$ & $\%$ of GDP & U.S.\$ & $\%$ of GDP & U.S.\$ & $\%$ of GDP \\
\hline & 2.4 & 0.27 & 6.4 & 0.71 & 6.4 & 0.71 & 6.2 & 0.69 & 6.2 & 0.69 \\
\hline Russia & 11.5 & 2.10 & 11.8 & 2.15 & 11.8 & 2.15 & 11.6 & 2.11 & 11.6 & 2.11 \\
\hline India & 2.1 & 0.24 & 8.1 & 0.95 & 8.0 & 0.94 & 15.2 & 1.79 & 18.0 & 2.12 \\
\hline Indonesia & 4.4 & 1.70 & 8.6 & 3.34 & 11.7 & 4.52 & 13.3 & 5.16 & 13.3 & 5.16 \\
\hline China & -0.7 & -0.03 & -0.5 & -0.02 & 2.0 & 0.10 & 14.5 & 0.70 & 18.8 & 0.91 \\
\hline South Africa & 2.7 & 1.32 & 2.7 & 1.35 & 2.7 & 1.35 & 2.6 & 1.30 & 2.6 & 1.28 \\
\hline Global & 172.2 & & 244.0 & & 248.2 & & 279.0 & & 286.4 & \\
\hline
\end{tabular}

Unilateral Free Trade

\begin{tabular}{lrr} 
& \multicolumn{2}{c}{ Welfare } \\
Brazil & U.S.\$ & \% of GDP \\
\cline { 2 - 3 } Global & 26.0 & 2.91 \\
Russia & 73.9 & \\
Global & 24.9 & 4.53 \\
India & 83.1 & \\
Global & 28.8 & 3.40 \\
Indonesia & 102.2 & \\
Global & 12.1 & 4.70 \\
China & 40.0 & \\
Global & 107.1 & 5.19 \\
South Africa & 253.4 & \\
Global & 12.0 & 5.94 \\
\hline
\end{tabular}

Global Free Trade

\begin{tabular}{lrr}
\hline & \multicolumn{2}{c}{ Welfare } \\
\cline { 2 - 3 } Brazil & U.S.\$ & $\%$ of GDP \\
\cline { 2 - 3 } Russia & 26.4 & 2.94 \\
India & 41.0 & 7.48 \\
Indonesia & 26.6 & 10.30 \\
China & 131.4 & 6.37 \\
South Africa & 16.2 & 8.05 \\
Global & 2870.1 & \\
\hline
\end{tabular}

